\title{
Using palynological evidence from royal jelly to mediate the spread of Paenibacillus larvae in Brazil
}

\author{
Dib Cynthia Fernandes Pinto da Luz ${ }^{1,8}$, Lubiane Guimarães-Cestaro ${ }^{2}$, José Eduardo Serrão ${ }^{3}$, Dejair Message ${ }^{4}$, \\ Marta Fonseca Martins ${ }^{5}$, Maria Luisa Teles Marques Florêncio Alves ${ }^{6}$, María Carmen Seijo-Coello ${ }^{7}$ and \\ Érica Weinstein Teixeira ${ }^{6}$
}

Received: 27.04.2018; accepted: 11.07.2018

\begin{abstract}
Using palynological evidence from royal jelly to mediate the spread of Paenibacillus larvae in Brazil). Royal jelly may contain pollen grains and their presence can be used to determine the phytogeographical origin of the product. This study analyzed the phytogeographical origin of commercial royal jelly samples from São Paulo State, tested as part of the Brazilian Federal Inspection System (SIF), found to be contaminated with spores of the bacterium Paenibacillus larvae, that causes the American Foulbrood Disease. The pollen grains of Castanea had the highest total percentage, with lower percentages of Cirsium/Carduus, Cistus, Parthenocissus, Prunus, Quercus, Robinia, Scrophulariaceae, Taraxacum, Tilia, among others. This pollen spectrum is incompatible with royal jelly samples produced in Brazil. The pollen spectrum resembled that of an imported product, compatible with the Northern Hemisphere origin. Brazilian legislation does not require the phytogeographic origin of imported bee products to be analyzed by palynological procedures, but it is mandatory to have a certificate issued by the country of origin attesting the absence of pathogens, monitored with the objective of preventing the exotic diseases from entering Brazil. Palynology, therefore, proved to be fundamental in detecting imports of this contaminated batches.
\end{abstract}

Keywords: Apis mellifera, Forensic palynology, foulbrood disease, Melissopalynology, pollen analysis

RESUMO - (Usando evidências palinológicas em geléia real para intervir na disseminação de Paenibacillus larvae no Brasil). A geléia real pode conter grãos de pólen e sua presença pode ser usada para determinar a origem fitogeográfica do produto. Este estudo analisou a origem fitogeográfica de amostras comerciais de geléia real do Estado de São Paulo, com registro no Sistema de Inspeção Federal (SIF) brasileiro, que estavam contaminadas com os esporos da bactéria Paenibacillus larvae, causadora da doença Cria Pútrida Americana. Os grãos de pólen de Castanea apresentaram a maior porcentagem total, com menores percentuais de Cirsium/Carduus, Cistus, Parthenocissus, Prunus, Quercus, Robinia, Scrophulariaceae, Taraxacum, Tilia, dentre outros. Este espectro polínico é incompatível com amostras de geléia real produzidas no Brasil. O espectro polínico assemelhou- se ao de um produto importado, compatível com a origem do Hemisfério Norte. A legislação brasileira não exige que a origem fitogeográfica dos produtos apícolas importados seja analisada por procedimentos palinológicos, mas é obrigatório ter um certificado atestando a ausência de patógenos emitido pelo país de origem, monitorado com o objetivo de impedir que doenças exóticas penetrem no Brasil. A palinologia, portanto, provou ser fundamental na detecção de importações desses lotes contaminados.

Palavras-chave: Análise polínica, Apis mellifera, cria pútrida americana, Melissopalinologia, Palinologia forense

\section{Introduction}

A decline in the honey bee population has been reported in various countries over the past decade by the FAO (United Nations Food and Agriculture Organization) and the NAS (U.S. National Academy of Sciences), including populations in Brazil. This is a matter of great concern due to the decline in

1. Instituto de Botânica, Núcleo de Pesquisa em Palinologia, Avenida Miguel Stéfano, 3.687, 04301-902 São Paulo, SP, Brasil

2. Universidade Federal de Viçosa, Pós-gradução em Entomologia, Departamento de Entomologia, 36570-900 Viçosa, MG, Brasil

3. Universidade Federal de Viçosa, Departamento de Biologia Geral, 36570-900 Viçosa, MG, Brasil

4. Universidade Federal Rural do Semi-Árido, Departamento de Ciências Animais, 59625-900 Mossoró, RN, Brasil

5. Empresa Brasileira de Pesquisa Agropecuária, Embrapa Gado de Leite, 36038-330 Juiz de Fora, MG, Brasil

6. Agência Paulista de Tecnologia dos Agronegócios, Polo Regional Vale do Paraíba, 12400-970 Pindamonhangaba, SP, Brasil

7. Universidade de Vigo, Departamento de Biologia Vegetal e Ciências do Solo, Ourense, Espanha

8. Corresponding author: cyluz@yahoo.com 
pollination of important food crops (Klein et al. 2007). The honey bee mortality observed is not seasonal and there seems to be a complex interaction between various factors, including insecticide application by farmers as well as fragmentation and degradation of habitats (Johnson 2010). However, the data are still imprecise and the causes are undefined due to the absence of standards and/or weak monitoring (Pires et al. 2016).

Although honey bees are attacked by many parasites and pathogens (Chen et al. 2004), Africanized bees are more tolerant and resistant to several pathogens. However, in recent years there has been a sudden weakening of swarms in various places in the southeast of Brazil, with mortality of adult bees and the appearance of abnormal symptoms in broods (Message et al. 2012).

American foulbrood disease, caused by the bacterium Paenibacillus larvae, one of the main cause of losses of colonies in the world (Funfhaus et al. 2013). This pathogen contaminates colonies through spore ingestion by larvae (Garrido-Bailón et al. 2013), causing their death, consequently a decrease in the colony population. The bacterium $P$. larvae is exotic in Brazil and American foulbrood disease was only detected twice in the country. The disease was detected for the first time in 2001 in the municipality of Candelária, Rio Grande do Sul State, where samples of adult bees, honey, pollen and honeycombs were collected and analyzed (Schuch et al. 2003). Spores of the bacterium were detected in three groups of adult bees and in honeycombs, as well as in imported honey and pollen samples. In 2006, clinical signs of the disease were reported in samples from Quatro Barras, Paraná State. This bacterium was quickly controlled and extinguished in the country (MAPA 2006).

Exotic diseases can enter new territories by natural migration of bees, or by importing queen bees or bee products contaminated with pathogens (Hitchcock \& Revell 1963, Gochnauer \& Corner 1974, Hale \& Menapace 1980, Flores et al. 2005, Higes et al. 2008, Pettis et al. 2013, Fries et al. 2013, OIE 2014, Guimarães-Cestaro et al. 2016). Diseases caused by microorganisms are of particular concern due to the easy transmission of resistant spores, which can remain viable for decades (Hornitzky 2010). For example, spores of $P$. larvae can remain viable for about 70 years in the environment (Shimanuki \& Knox 1994, 2000).

Inside the bee colony, products such as honey, pollen, and royal jelly are susceptible to contamination by these pathogens, mainly by being stored in comb cells by the bees and transferred through trophallaxis (OIE 2014). Due to the high risk of introducing exotic pathogens into the country by imported bees' products and queens, sanitary control is regulated by a specific resolution of the Brazilian Ministry of Agriculture. Among the requirements are documents from the country of origin that include the results of diagnostic tests.

Royal jelly is a product secreted by the hypopharyngeal glands of worker honeybees (Apis mellifera). It is derived mostly from the nutrients contained in the pollen grains ingested by the bees. Pollen is the main source of proteins, peptides and secondary metabolites in royal jelly. Therefore, pollen is the main precursor product that results in royal jelly and substantially influences its biological properties (Stocker 2005). Although it does not make sense to refer to the botanical origin of royal jelly, because it is a bee secretion, observing the pollen types and their percentages (pollen spectra) can provide some evidence regarding the phytogeographical origin of a royal jelly sample. Pollen flow into the product is an accidental process, introduced from the internal environment of the colony, during manipulation in the mouthparts of the adult bees when feeding queen larvae or adult queens. As the royal jelly is not stored in the hive, it can be found pollen grains that happened to be in the bees' bodies or in their nectariferous vesicles (Simpson 1955, Renner et al. 2003, Barth 2005).

Pollen grains analysis in bee products is an effective tool to support the certification of their phytogeographical origin because it shows the presence of pollen types that are characteristic of specific plants. However, according to Brazilian legislation, this analysis is not mandatory for imported or local bee products.

There are few palynological studies of royal jelly (Chauvin \& Louveaux 1956, Ricciardelli D'Albore et al. 1977, Ricciardelli-D'Albore \& Battaglini 1978, Biondi et al. 2003, Piana et al. 2006, Dimou et al. 2007, Dimou et al. 2013). In Brazil, only the studies carried out by (Barth 2005) and (Morgado \& Barth 2011) can be found, which samples are rich in pollen grains of Asteraceae, Cecropia, Eucalyptus, Melastomataceae and Mimosa pudica/M. scabrella.

This study evaluated the phytogeographical origin of royal jelly samples sold in São Paulo State, Brazil, tested by the Federal Inspection System (Sistema de Inspeção Federal - SIF) in which positive signs of Paenibacillus larvae were previously detected based 
on PCR results. The results of these analyses are useful for elucidating the possible dispersion of this pathogen in Brazil through the sale and distribution of bee products.

\section{Material and methods}

Eight royal jelly samples, which were inspected by the S.I.F., were analyzed using palynological techniques. They were purchased in São Paulo State, Brazil and were bottled from 2012 to 2014. Positive signs of Paenibacillus larvae were detected according to molecular analyses (Guimarães-Cestaro et al. 2016, Teixeira et al. 2018).

The palynological treatment of the royal jelly followed Barth (2005) using $1 \mathrm{~g}$ of the product for the analysis and preparation of the microscope slides which include sample dilution, centrifugation, resuspension in acetic acid for overnight dehydration, and subsequent acetolysis (Erdtman 1952). Three slides of each sample were prepared using standard uncolored and fuchsine stain colored (one slide) glycerine jelly (Barth 2005). Fuchsin stained pollen grains were not photographed.

The identification of the pollen types was based on the European and Asian pollen flora catalogs (Punt \& Clarke 1974, Lieux 1975-1977-1978, Göschl 2008, Haiqing 2015), among many publications that were consulted and that are part of the collection from the Palynological Research Centre (NPP) at the Institute of Botany, as well as others obtained from the Internet. The "Northwest European Pollen Flora" (Punt \& Clarke 1974) is the world's most detailed pollen morphological study and covers around 130 families and ca. 600 species.

In the present study was adopted as counting methodology the observation of all pollen grains contained in the three slides. Pollen grains were identified as "pollen types" meaning that a single plant species, group of species or higher taxa could present with similar pollen morphologies.

In order to evaluate the phytogeographical origin of each sample, the percentage calculation representing all the pollen types per sample (Total Pollen Sum) was used. The pollen types were grouped according to their relative frequencies, following (Louveaux et al. 1978), corresponding to: Predominant pollen $(\mathrm{P})=>45 \%$ of the total pollen grains counted; Secondary pollen $(\mathrm{S})=16 \%$ to $45 \%$; Important Minor Pollen (I) $=3 \%$ to $15 \%$ and, Minor pollen $(\mathrm{M})=<3 \%$.

Although quantification by Lycopodium tracer spores provides a context for pollen spectra that is both useful for supporting phytogeographic origins of bee products from botanical source (bee pollen and honey) and, for later comparisons with similar studies, they were not utilized in this study to collect pollen data, due to the fact that royal jelly is a question of bee secretion. The pollen concentration calculation in royal jelly has no use whatsoever, as it does not come from botanical excretions. In addition, pollen concentration calculations using Lycopodium tracer spores were only carried out in royal jelly in Barth (2005) and Morgado \& Barth (2011) studies, and even so, without an important discussion about it. Lycopodium tracer spores were not used in royal jelly in the studies conducted by Chauvin \& Louveaux (1956), Ricciardelli D'Albore et al. (1977), Ricciardelli-D'Albore \& Battaglini (1978), Biondi et al. (2003), Piana et al. (2006), Dimou et al. (2007), Dimou et al. (2013). Another reason for not having done concentration calculation and saturation curve is that this is a product manipulated for commercialization, without possibility to control the field production, as observed in other studies, like e.g., in Dimou et al. (2007), and there is no way of knowing if these samples suffered some type of filtering before being commercialized. Filtering could have artificially reduced the pollen quantity. Finally, in forensic terms, you never add something to a pollen sample and especially not other spores or pollen.

The similarity between the samples was analyzed using a principal component analysis (PCA) to examine the influence of quantitative and qualitative data on the ordination of the pollen types. The matrix included the absolute value of all pollen types counted in each sample. The FITOPAC software Shepherd (1996) was used for the transformation of the absolute count using the natural logarithm $[\log (\mathrm{x}+1)]$ and the ordination was subsequently performed using the covariance matrix in the PC-ORD 5.0 software (Mccune \& Mefford 1999). The variability between samples was expressed using the first two axes of the PCA.

The MINITAB 15 software (Minitab Inc., State College, PA, 2003) was used to construct a dendrogram of the percent of similarity between the samples.

The samples were evaluated in two ways to identify its origin: 1) among samples, to verify its similarity, including all the pollen types and their absolute value and, 2) with those from other countries, to compare the pollen types found in each sample together with the presence or absence in royal jelly 
samples from Brazil (Barth 2005, Morgado \& Barth 2011), China (Piana et al. 2006), France (Stocker 2005), Greece (Dimou et al. 2013) and Italy (Piana et al. 2006) as well as Louisiana honey, United States (Lieux 1975-1977-1978). This allowed investigating if a possible illegal event occurred that could pose serious environmental risks due to the possibility of dispersing this exotic pathogen in Brazil.

The pollen types were grouped in a table showing their probable geographical origins, habitus (form) of the plant, vernacular names in Portuguese and in English, the presence or absence in the samples and a possible indication of the Brazilian extra origin.

The image captures of pollen grains were obtained using an OLYMPUS BX 50 light microscope with a video camera Olympus U-CMAD-2 and the program CellSens Standard ${ }^{\circledR}$ 1.5. for Windows.

\section{Results and Discussion}

We identified 78 pollen types representing 48 genera and 38 families of plants, in eight royal jelly samples (table 1). In addition, there were 16 unidentified pollen types. Some samples contained only very few pollen grains as observed also by Dimou et al. (2013) in Greece.

No samples showed pollen spectra compatible with Brazilian biomes or degraded areas by anthropic action of the country (table 2).

Several pollen types found in the samples were from cultivated plants for food, medicinal or ornamental purposes in many parts of the world (Allium, Apium, Brassicaceae, Daucus, Lilium, Taraxacum, Zea mays, among others). Pollen grains from these plants are not good indicators of phytogeographical origin as they can occur in various continents.

On the other hand, the pollen types Acer negundo, Betula, Castanea, Cistus, Cytisus, Hypecoum, Larix, Nyssa, Quercus, Robinia, Sambucus, Saxifraga, Tilia and Ulmus are excellent indicators of origin of samples outside Brazil.

The pollen spectra observed differed from those reported by Barth (2005) and Morgado \& Barth (2011) for royal jelly samples produced in Brazil, which include a predominance of Cecropia, Asteraceae and Eucalyptus in the city of Viçosa (Minas Gerais State) and Cecropia, Eucalyptus, Melastomataceae and Mimosa pudica/M. scabrella in Pindamonhangaba (São Paulo State), among other pollen grains with lower frequencies. These groups are very distinct from those of the Northern Hemisphere. The pollen spectra of the samples from Pindamonhangaba are similar to those from Vietnam (Piana et al. 2006) due to the presence of Mimosa pudica and Eucalyptus, but with different percentages. Another differentiating factor was the presence of other pollen types that only occur in either one of the countries.

The pollen spectra found in the analyzed samples indicate the presence of pollen grains from exotic plants such as thistles (Cirsium/Carduus), oak (Quercus), chestnut (Castanea), rockrose (Cistus), locusts (Robinia), woodbine or ivy (Parthenocissus), tilia (Tilia) and red clover (Trifolium pratense), among others. Several of these pollen grains are reported in European (Louveaux 1970, Ricciardelli-D'Albore \& Intoppa 2000), American (Lieux 1975-1977-1978) or Chinese honey (Song et al.2012), with some regional variations in frequencies.

The pollen variability among the samples comprised $69.68 \%$ of the two first axes in the PCA (figure 1). The first axis summed for $53.85 \%$ of the variance due to the high values of Castanea, Brassicaceae, Daucus and Taraxacum pollen types which were found in seven samples, as well as Parthenocissus and Veronica, in six and five samples, respectively (table 3 ).

Among the main pollen grains, those from Castanea were found in all analyzed samples and Predominant (P) in samples GR1, GR5, GR8 and GR10 whereas in samples GR2 and GR9 it was Secondary (S). However, in samples GR3 and GR4 it occurred as an Important minor pollen (I) (table 1).

The chestnut is a deciduous tree native to temperate regions of the Northern Hemisphere (North America, Asia and Europe), but it is cultivated in Brazil in some places in São Paulo State, where there are commercial orchards established as long as 20 years ago in Arapeí, Campinas, Campos de Jordão, Cunha, Itupeva, Itapecerica da Serra, Mogi Mirim, Piedade, Pindamonhangaba, Santo Antônio do Pinhal, São Bento do Sapucaí, São José dos Campos and Taubaté (Bueno \& Pio 2014). In Minas Gerais State, the commercial orchards are located in the southern region, in Brazópolis, Conceição dos Ouros, Espírito Santo do Dourado, Pouso Alegre, Jacutinga and Gonçalves (Bueno \& Pio 2014). However, as several other pollen types observed in all samples did not belong to Brazilian plants, it can be claimed that all samples analyzed were imported.

Other important pollen types for PCA ordination that did not occur frequently in the samples were 
Table 1. Frequencies of pollen types in the royal jelly samples with Paenibacillus larvae spores purchased in São Paulo State, Brazil, inspected by the S.I.F. Predominant pollen (P), $>45 \%$ of the total pollen grains counted; Secondary pollen $(\mathrm{S})=$ $16 \%$ to $45 \%$. Obs: values are in percentage. The designations after pollen type name indicate the code used in the PCA.

\begin{tabular}{|c|c|c|c|c|c|c|c|c|}
\hline Samples & GR1 & GR2 & GR3 & GR4 & GR5 & GR8 & GR9 & GR10 \\
\hline \multicolumn{9}{|l|}{ Pollen types/codes } \\
\hline \multicolumn{9}{|l|}{ Gymnospermae } \\
\hline Cupressaceae/Cupre & 0 & 0 & 0 & 0 & 0 & 0 & 0.62 & 0 \\
\hline Larix (Pinaceae)/Larix & 0 & 0 & 2.44 & 0 & 0 & 0 & 0 & 0 \\
\hline \multicolumn{9}{|l|}{ Angiospermae monocotiledons } \\
\hline Allium (Amaryllidaceae)/Alliu & 1.35 & 0 & 0 & 0 & 0 & 0 & 0 & 0 \\
\hline Iridaceae/Irida & 0 & 0 & 2.44 & 0 & 0 & 0 & 0 & 0 \\
\hline Lilium (Liliaceae)/Lili & 0 & 0 & 0 & 0 & 0 & 0 & 0 & 0.97 \\
\hline Monocotiledon rugulate/Monrug & 0 & 0 & 0 & 0 & 0 & 5 & 0 & 0 \\
\hline Monocotiledon 2/Mon2 & 0 & 0 & 0 & 0 & 0 & 0 & 0.31 & 0 \\
\hline Monocotiledon reticulate/Monret & 0 & 0 & 0 & 0 & 0 & 0 & 0.62 & 0 \\
\hline Monocotiledon rugulate 2/Monrug2 & 0 & 0 & 0 & 0 & 0 & 0 & 0 & 0.97 \\
\hline Poaceae/Poa & 1.35 & 0 & 2.44 & 1.35 & 0.75 & 0 & 0 & 0 \\
\hline Zea mays (Poaceae)/Zea & 0 & 0 & 0 & 0 & 0 & 0 & 0.93 & 0 \\
\hline \multicolumn{9}{|l|}{ Angiospermae eudicotiledons } \\
\hline Sambucus (Adoxaceae)/Sam & 1.35 & 0 & 0 & 0 & 0 & 0 & 0 & 0 \\
\hline Amaranthaceae-Chenopodiaceae/Amar & 0 & 0 & 0 & 0 & 0 & 0 & 0.31 & 0.97 \\
\hline Apium (Apiaceae)/Apium & 0 & 5.88 & 0 & 0 & 0 & 0 & 0 & 0 \\
\hline Daucus (Ápiaceae)/Dauc & 2.70 & 5.88 & 2.44 & 1.35 & 0.75 & 0 & 10.52 & 0.97 \\
\hline Pleurospermum (Apiaceae)/Pleur & 0 & 5.88 & 0 & 0 & 0 & 0 & 0 & 0 \\
\hline Ilex (Aquifoliaceae)/Ilex & 2.70 & 0 & 0 & 0 & 0 & 0 & 0 & 0 \\
\hline Ambrosia (Asteraceae)/Ambro & 0 & 0 & 0 & 0 & 0 & 5 & 0 & 0 \\
\hline Artemisia (Asteraceae)/Arte & 0 & 0 & 0 & 0 & 0 & 2.5 & 0 & 0 \\
\hline Asteraceae 1/Aster1 & 1.35 & 5.88 & 0 & 0 & 0 & 5 & 2.78 & 0 \\
\hline Asteraceae 2/Aster2 & 2.70 & 0 & 0 & 0 & 0 & 0 & 0 & 0 \\
\hline Asteraceae 3/Aster3 & 0 & 0 & 0 & 0 & 0 & 0 & 0.93 & 2.91 \\
\hline Asteraceae 4/Aster4 & 0 & 0 & 2.44 & 0 & 0 & 0 & 0.31 & 0 \\
\hline Asteraceae 5/Aster5 & 0 & 0 & 0 & 0 & 0 & 0 & 0 & 0.97 \\
\hline Cirsium-Carduus (Asteraceae)/Cardu & 1.35 & 0 & 0 & 0 & 0 & 2.5 & 0 & 0 \\
\hline Senecio (Asteraceae)/Sene & 2.70 & 0 & 0 & 1.35 & 0 & 0 & 0 & 0 \\
\hline Taraxacum (Asteraceae)/Tarax & 1.35 & 5.88 & 0 & 1.35 & 0.75 & 5 & 1.54 & 0.97 \\
\hline Betula $($ Betulaceae$) /$ Betu & 1.35 & 0 & 0 & 0 & 0 & 2.5 & 1.54 & 0.97 \\
\hline Brassicaceae/Brassi & 1.35 & $17.64(\mathrm{~S})$ & 7.32 & $32.43(\mathrm{~S})$ & 1.50 & 0 & 1.24 & 0.97 \\
\hline Myosotis (Boraginaceae)/Myos & 0 & 5.88 & 0 & 0 & 0 & 0 & 1.24 & 0 \\
\hline Caryophylaceae 1/Caryo & 0 & 0 & 2.44 & 0 & 0 & 0 & 0.31 & 0 \\
\hline Melandrium (Caryophyllaceae)/Mela & 0 & 0 & 0 & 0 & 0 & 0 & 0.62 & 0 \\
\hline Cistus (Cistaceae)/Cistus & 1.35 & 0 & 7.32 & 0 & 1.50 & 0 & 0.93 & 0 \\
\hline Helianthemum (Cistaceae)/Helia & 0 & 0 & 0 & 1.35 & 0 & 2.5 & 0.31 & 1.94 \\
\hline Nyssa (Cornaceae)/Nyssa & 1.35 & 0 & 0 & 0 & 4.51 & 0 & 1.24 & 1.94 \\
\hline Euphorbiaceae/Eupho & 0 & 0 & 0 & 0 & 0 & 0 & 0.31 & 0.97 \\
\hline Cassia (Fabaceae)/Cassia & 1.35 & 0 & 0 & 0 & 0 & 0 & 0 & 0 \\
\hline Cytisus (Fabaceae)/Cytis & 0 & 0 & 2.44 & 0 & 0 & 0 & 0 & 0 \\
\hline Mimosa pudica (Fabaceae)/Mimpu & 0 & 0 & 0 & 0 & 0 & 2.5 & 0 & 0 \\
\hline Robinia (Fabaceae)/Robi & 0 & 0 & $19.51(\mathrm{~S})$ & 0 & 0 & 0 & 0 & 0 \\
\hline Fabaceae1/Faba1 & 1.35 & 0 & 0 & 0 & 0 & 0 & 0.62 & 0 \\
\hline Fabaceae 2/Faba2 & 0 & 5.88 & 0 & 0 & 0 & 0 & 0 & 0 \\
\hline Fabaceae 3/Faba3 & 0 & 0 & 7.32 & 0 & 0 & 0 & 0 & 0 \\
\hline Fabaceae 4/Faba4 & 0 & 0 & 0 & 1.35 & 0 & 0 & 0 & 0 \\
\hline Lotus corniculatus (Fabaceae)/Lotus & 0 & 0 & 2.44 & $16.21(\mathrm{~S})$ & 0.75 & 0 & 0 & 0 \\
\hline Trifolium (Fabaceae)/Trifo & 0 & 5.88 & 0 & 0 & 0 & 0 & 0 & 0 \\
\hline Trifolium incarnatum (Fabaceae)/Trifoin & 0 & 0 & 0 & 0 & 0.75 & 0 & 1.86 & 0.97 \\
\hline
\end{tabular}


Table 1 (continuation)

\begin{tabular}{|c|c|c|c|c|c|c|c|c|}
\hline Samples & GR1 & GR2 & GR3 & GR4 & GR5 & GR8 & GR9 & GR10 \\
\hline \multicolumn{9}{|l|}{ Pollen types/codes } \\
\hline Trifolium pratense (Fabaceae)/Trifopra & 0 & 0 & 2.44 & 6.75 & 0 & 0 & 0 & 0 \\
\hline Trifolium repens (Fabaceae)/Triforep & 0 & 0 & 0 & 0 & 0 & 0 & 1.55 & 0 \\
\hline Vicia faba (Fabaceae)/Vicia & 0 & 0 & 0 & 9.46 & 0 & 0 & 0 & 0 \\
\hline Castanea (Fagaceae)/Casta & $52.70(\mathrm{P})$ & $29.41(\mathrm{~S})$ & 4.87 & 4.05 & $57.14(\mathrm{P})$ & $45(\mathrm{P})$ & $41.79(\mathrm{~S})$ & $64.07(\mathrm{P})$ \\
\hline Quercus (Fagaceae)/Quercus & 0 & 0 & 0 & 2.70 & 0 & 0 & 4.02 & 0.97 \\
\hline Hypecoum (Fumariaceae)/Hypec & 0 & 0 & 0 & 0 & 0.75 & 0 & 0 & 0 \\
\hline Gentianaceae/Genti & 0 & 0 & 7.32 & 0 & 0 & 0 & 0 & 0 \\
\hline Lamiaceae/Lami & 0 & 0 & 0 & 0 & 0 & 0 & 0.31 & 0 \\
\hline Salvia (Lamiaceae)/Salvia & 0 & 0 & 0 & 0 & 0 & 2.5 & 0 & 0 \\
\hline Vitex (Lamiaceae)/Vitex & 0 & 0 & 0 & 8.11 & 0 & 0 & 0 & 0 \\
\hline Tilia (Malvaceae)/Tilia & 1.35 & 0 & 2.44 & 0 & 0 & 0 & 0 & 0 \\
\hline Meliaceae1/Meli1 & 0 & 0 & 0 & 0 & 0 & 0 & 0 & 0.97 \\
\hline Meliaceae 2/Meli2 & 1.35 & 0 & 0 & 0 & 0 & 0 & 0 & 0 \\
\hline Meliaceae 3/Meli3 & 0 & 0 & 0 & 0 & 0 & 0 & 0.62 & 0 \\
\hline Ligustrum (Oleaceae)/Ligus & 0 & 0 & 0 & 0 & 0 & 0 & 2.47 & 0 \\
\hline Fagopyrum (Polygonaceae)/Fago & 0 & 0 & 0 & 6.75 & 0 & 0 & 0 & 0 \\
\hline Rumex (Polygonaceae)/Rumex & 1.35 & 0 & 0 & 0 & 0 & 0 & 0 & 0 \\
\hline Veronica (Plantaginaceae)/Vero & 2.70 & 0 & 0 & 0 & 0.75 & 12.5 & 7.74 & 3.88 \\
\hline Primulaceae/Prim & 0 & 5.88 & 0 & 0 & 0 & 0 & 0 & 0 \\
\hline Caltha (Ranunculaceae)/Caltha & 0 & 0 & 0 & 0 & 0.75 & 0 & 0 & 0 \\
\hline Thalictrum (Ranunculaceae)/Thali & 1.35 & 0 & 2.44 & 0 & 0 & 0 & 0 & 0 \\
\hline Prunus (Rosaceae)/Prunus & 1.35 & 0 & 4.87 & 1.35 & 1.50 & 0 & 0 & 0 \\
\hline Rubus (Rosaceae)/Rubus & 0 & 0 & 0 & 0 & 0 & 0 & 2.78 & 0 \\
\hline Borreria (Rubiaceae)/Borr & 1.35 & 0 & 0 & 0 & 0 & 0 & 0 & 0 \\
\hline Salix (Salicaceae)/Salix & 0 & 0 & 0 & 1.35 & 4.51 & 0 & 0.31 & 0.97 \\
\hline Acer negundo (Sapindaceae)/Acneg & 0 & 0 & 4.87 & 0 & 1.50 & 0 & 1.24 & 0.97 \\
\hline Saxifraga (Saxifragaceae)/Saxi & 0 & 0 & 2.44 & 0 & 0 & 0 & 0 & 0 \\
\hline Solanaceae/Sola & 0 & 0 & 0 & 0 & 0 & 0 & 0.31 & 0 \\
\hline Solanum (Solanaceae)/Solu & 1.35 & 0 & 2.44 & 1.35 & 0 & 0 & 0 & 0 \\
\hline Ulmus (Ulmaceae)/Ulmus & 1.35 & 0 & 2.44 & 1.35 & 0 & 0 & 0 & 0 \\
\hline Parthenocissus (Vitaceae)/Parth & 4.05 & 0 & 2.44 & 0 & $18.79(\mathrm{~S})$ & 5 & 2.47 & 7.76 \\
\hline Non Identified 1/NI1 & 1.35 & 0 & 0 & 0 & 0 & 0 & 0 & 0 \\
\hline Non Identified 5/NI5 & 1.35 & 0 & 0 & 0 & 0 & 0 & 0 & 0 \\
\hline Non Identified 7/NI7 & 0 & 0 & 0 & 0 & 0.75 & 0 & 0.31 & 0 \\
\hline Non Identified 12/NI12 & 0 & 0 & 0 & 0 & 0 & 0 & 0 & 0.97 \\
\hline Non Identified 13/NI13 & 0 & 0 & 0 & 0 & 1.50 & 0 & 0 & 0 \\
\hline Non Identified 14/NI14 & 0 & 0 & 0 & 0 & 0 & 0 & 0 & 0.97 \\
\hline Non Identified 15/NI15 & 0 & 0 & 0 & 0 & 0.75 & 0 & 0 & 0 \\
\hline Non Identified 16/NI16 & 0 & 0 & 0 & 0 & 0 & 2.5 & 0 & 0 \\
\hline Non Identified 19/NI19 & 0 & 0 & 0 & 0 & 0 & 0 & 0.62 & 0 \\
\hline Non Identified 20/NI20 & 0 & 0 & 0 & 0 & 0 & 0 & 0.62 & 0 \\
\hline Non Identified 21/NI21 & 0 & 0 & 0 & 0 & 0 & 0 & 2.16 & 0 \\
\hline Non Identified 22/NI22 & 0 & 0 & 0 & 0 & 0 & 0 & 0.31 & 0 \\
\hline Non Identified 23/NI23 & 0 & 0 & 0 & 0 & 0 & 0 & 0.31 & 0 \\
\hline Non Identified 24/NI24 & 0 & 0 & 0 & 0 & 0 & 0 & 0.31 & 0 \\
\hline Non Identified 25/NI25 & 0 & 0 & 0 & 0 & 0 & 0 & 0 & 1.94 \\
\hline Non Identified 27/NI27 & 0 & 0 & 0 & 0 & 0 & 0 & 0.62 & 0 \\
\hline
\end{tabular}




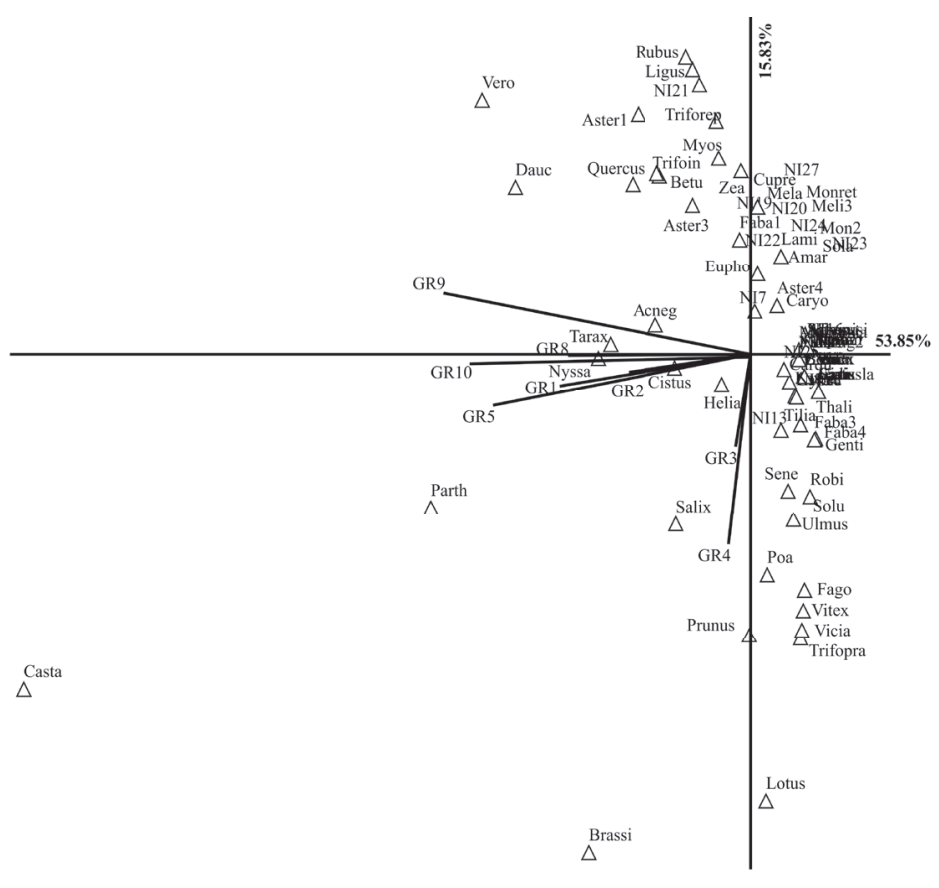

Figure 1. Principal Component Analysis performed with the pollen type counting variables in eight royal jelly samples with Paenibacillus larvae spores purchased in São Paulo State, Brazil. Codes for pollen types can be found in Table 1.

Table 2. Geographical origin, life form, vernacular names, economic data of plant usage, and the main occurring environment in Brazil of the plants identified at the genus level by means of the pollen types found in the royal jelly samples with Paenibacillus larvae spores purchased in São Paulo State, Brazil. Note: "Native" means a plant indigenous to a particular region, "Naturalized" means after being introduced into a region, develops without the need to be treated or cultivated under human intervention and "Exotic" means introduced from abroad, but not fully naturalized. Native and naturalized vegetation quoted by Flora do Brasil (Brazilian Flora).

$\begin{array}{ccccc}\text { Pollen types } & \text { Life } & \begin{array}{c}\text { English and } \\ \text { fortuguese } \\ \text { form } \\ \text { vernacular names } \\ \text { (when available) }\end{array} & \begin{array}{c}\text { Geographical origin and economical } \\ \text { use of the correspondent plants }\end{array} & \begin{array}{c}\text { Presence on } \\ \text { samples }\end{array}\end{array}$ Ocurrence in Brazil

Gymnospermae

Cupressaceae tree $\begin{aligned} & \text { cypress, cedar, etc/ } \\ & \text { cipreste, cedro, etc }\end{aligned}$

Larix (Pinaceae) tree $\begin{gathered}\text { larches/alerce, } \\ \text { larício, lariço or } \\ \text { larice }\end{gathered}$

Native in the temperate regions with milder temperatures of both hemispheres. They are valuable for timber, production of gums or resins and with ornamental value.

Native conifer of most of the Northern Hemisphere, Eurasia and North America, inhabited the cooler temperate climate, from the lowlands to high mountains. It is one of the dominant plants in the immense boreal forests of Russia, Canada and Scandinavia.
Exotic. None is native to Brazil, but can be found

GR9 sporadically as an ornamental plant in gardens and parks.

\section{GR3}

Exotic. None is native to Brazil. 
Table 2 (continuation)

\begin{tabular}{lcccc}
\hline & English and & & \\
Pollen types & $\begin{array}{c}\text { Life } \\
\text { form }\end{array}$ & $\begin{array}{c}\text { Portuguese } \\
\text { vernacular names } \\
\text { (when available) }\end{array}$ & $\begin{array}{c}\text { Geographical origin and economical } \\
\text { use of the correspondent plants }\end{array}$ & $\begin{array}{c}\text { Presence on } \\
\text { samples }\end{array}$ \\
\hline
\end{tabular}

Angiospermae

monocotiledons

Allium

(Amaryllidaceae)

Lilium (Liliaceae) herb lily/lírio

Zea mays

(Poaceae)

Angiospermae

eudicotiledons

Sambucus

(Adoxaceae)

Apium (Apiaceae) herb

Daucus

(Apiaceae)

Ilex

(Aquifoliaceae) tree,

shub

elder/sabugueiro

celery/aipo, salsão, etc

carrot, coriander, etc/cenoura, coentro, etc

tree, holly, maté/ shrub, azevinho, erva climber
Are annual or biennial bulbous plants that grow in temperate climates of the northern hemisphere. except for a few species growing in Chile, Brazil or in tropical Africa. Cultivated worldwide for food purposes.

Native of the northern hemisphere with occurrences in Europe, Asia, North America and South America. More than half of the species are found in China and Japan. Cultivated worldwide for ornamental value.

Native to Central America where it was domesticated for thousands of years.
GR1

Few native species in Brazil.

GR10

Exotic. Lilium formosanum A.

Wallace is an exotic naturalized and

Lilium longiflorum

Thunb. is cultivated in Brazil.

Exotic. It is one of the largest plantations in the world, together with wheat and rice, also in Brazil.

Only S. australis

Native in the temperate and subtropical regions of both hemispheres, with highest significance in the Northern Hemisphere. Cultivated worldwide for medicinal purposes.

Subcosmopolita distribution in Europe, Asia, Africa, South America and Australia.

GR2 Cham. \& Schltdl. is GR1 native in Brazil. $S$. nigra L. is an exotic naturalized.

Two species are exotic naturalized and several species cultivated for food purposes in Brazil.

Daucus carota is native to North America, Asia, Australia and Europe, Coriandrum sativum, is native to Africa, Asia and Europe.

Distributed in all temperate and subtropical regions of the world.
GR1, GR2, Exotic. Cultivated GR3, GR4, worldwide for food GR5, GR9, purposes, also in GR10 Brazil.

GR1
Several native species in Brazil. 
Table 2 (continuation)

\begin{tabular}{|c|c|c|c|c|}
\hline Pollen types & $\begin{array}{l}\text { Life } \\
\text { form }\end{array}$ & $\begin{array}{c}\text { English and } \\
\text { Portuguese } \\
\text { vernacular names } \\
\text { (when available) }\end{array}$ & $\begin{array}{l}\text { Geographical origin and economical } \\
\text { use of the correspondent plants }\end{array}$ & $\begin{array}{l}\text { Presence on } \\
\text { samples }\end{array}$ \\
\hline
\end{tabular}

Distributed in tropical and subtropical regions of the New World, especially

Ambrosia
(Asteraceae) $\quad$ herb $\quad$ ragweed/ambrósia

\section{Artemisia}

(Asteraceae)

Cirsium/Carduus

(Asteraceae)

herb thistle/cardo

herb,

shrub

mugwort, common wormwood/

artemisia

in North America where the origin

and genus diversity center are in

the southwestern United States and northwestern Mexico.

They grow in temperate climates in both hemispheres, usually in arid habitats or semi-arid.

GR8

Only Artemisia verlotorum Lamotte

is an exotic naturalized in Brazil.

Several species have been introduced

Native to Eurasia and North Africa, with about 60 species in North America.

GR1, GR8 worldwide for its ornamental value, also in Brazil.

Ragworts,

Senecio

(Asteraceae)

Taraxacum (Asteraceae)

$\begin{array}{lcc}\text { Betula } & \text { tree, } & \text { birch/bétula } \\ \text { (Betulaceae) } & \text { shrub }\end{array}$

herb, shrub groundsels / tasneira, tasna, erva-de-São-Tiago

herb dandelion/dentede-leão

Weeds of fields in Eurasia and North America.

Characteristic of temperate climate

shrub and has distribution as much in Asia as in Europe and North America.
GR1, GR2, GR4, GR5, GR8, GR9, GR10
Several native species in Brazil.

Exotic. None is native to Brazil.

Cultivated worldwide for its medicinal properties and ornamental value, also in Brazil.

Exotic. None is native to Brazil,

GR1, GR8, but can be found GR9, GR10 sporadically as an ornamental plant in gardens and parks.

Few native species

GR1, GR2, naturalized species

broccoli, cabbage, herb, cauliflower, kale, shrub, etc/brócolis, climber repolho, couveflor, couve, etc
Native to the northern coast of the

Mediterranean and Asia, having expanded later throughout Europe, as well as other continents. GR3, GR4, in Brazil. Cultivated GR5, GR9, GR10 worldwide for food purposes, also in Brazil. 
Table 2 (continuation)

\begin{tabular}{|c|c|c|c|c|}
\hline Pollen types & $\begin{array}{l}\text { Life } \\
\text { form }\end{array}$ & $\begin{array}{c}\text { English and } \\
\text { Portuguese } \\
\text { vernacular names } \\
\text { (when available) }\end{array}$ & $\begin{array}{l}\text { Geographical origin and economical } \\
\text { use of the correspondent plants }\end{array}$ & $\begin{array}{l}\text { Presence on } \\
\text { samples }\end{array}$ \\
\hline
\end{tabular}

\begin{tabular}{|c|c|c|c|}
\hline $\begin{array}{l}\text { Myosotis } \\
\text { (Boraginaceae) }\end{array}$ & herb & $\begin{array}{l}\text { forget-me-nots/ } \\
\text { não-me-esqueças }\end{array}$ & $\begin{array}{l}\text { Restricted to Eurasia and New } \\
\text { Zealand. One or two European } \\
\text { species, especially Myosotis sylvatica } \\
\text { were introduced in most temperate } \\
\text { regions of Europe, Asia and the } \\
\text { Americas. Very popular in gardens. }\end{array}$ \\
\hline Cistus (Cistaceae) & shrub & $\begin{array}{c}\text { rockrose, } \\
\text { laudanum/estevas, } \\
\text { ládano }\end{array}$ & $\begin{array}{l}\text { Native of the Mediterranean, from } \\
\text { the Canary Islands, off the coast of } \\
\text { Morocco to the Middle East coast. }\end{array}$ \\
\hline
\end{tabular}

Helianthemum

(Cistaceae)

herb, rockrose, /estevas, shrub rosa-da-pedra

Nyssa (Cornaceae) tree tupelo/tupelo canafistula, golden rain tree, cassia/ Pantropical distribution. The fruits are canafístula, canudo de pito, cássia

Cytisus

(Fabaceae)

$$
\begin{gathered}
\text { booms/chamiça, } \\
\text { giesteira }
\end{gathered}
$$

Native in open areas (typically brushwood and heathland) of Europe,
Widely distributed throughout the Northern Hemisphere, especially in the Mediterranean where it is the greatest diversity. They are distributed in America, Europe, and North Africa to Asia Minor and Central Asia.

It occurs spontaneously in North and Central America, from Mexico to Canada. Other species of Nyssa occur naturally in Southeast Asia, from China to the southwest of the Himalayas.

GR4, GR8, GR9, GR10

GR1, GR3, GR5, GR9

Exotic. Cultivated worldwide as ornamental plant, medicinal properties and to obtaining

Labdanum, an aromatic resin used in perfumery and in homeopathy.

Only Helianthemum brasiliense (Lam.) Pers. is native in Brazil. Cultivated worldwide as ornamental plant in gardens.

$\begin{array}{cc}\text { GR1, } & \text { No species of } \\ \text { GR5, } & \text { Nyssa occurs } \\ \text { GRontaneously in } \\ \text { Europe or in Brazil. }\end{array}$

Several native species in Brazil. The plant has ornamental value and also used in ayurvedic medicine. western Asia and North Africa.
Exotic. None is native to Brazil. 
Table 2 (continuation)

\begin{tabular}{|c|c|c|c|c|c|}
\hline Pollen types & $\begin{array}{l}\text { Life } \\
\text { form }\end{array}$ & $\begin{array}{c}\text { English and } \\
\text { Portuguese } \\
\text { vernacular names } \\
\text { (when available) }\end{array}$ & $\begin{array}{l}\text { Geographical origin and economical } \\
\text { use of the correspondent plants }\end{array}$ & $\begin{array}{l}\text { Presence on } \\
\text { samples }\end{array}$ & Ocurrence in Brazil \\
\hline $\begin{array}{l}\text { Mimosa pudica } \\
\text { (Fabaceae) }\end{array}$ & shrub & $\begin{array}{l}\text { sleepy plant, shy } \\
\text { plant, sensitive } \\
\text { plant, touch-me- } \\
\text { not /dormideira, } \\
\text { malícia, sensitiva }\end{array}$ & $\begin{array}{l}\text { Tropical origin. It is a native species of } \\
\text { Central and South America. Nowadays } \\
\text { is invasive, with pantropical } \\
\text { distribution, occurring in Africa, North } \\
\text { America, Asia and Australia. }\end{array}$ & GR8 & Native. \\
\hline $\begin{array}{l}\text { Robinia } \\
\text { (Fabaceae) }\end{array}$ & $\begin{array}{l}\text { tree, } \\
\text { shrub }\end{array}$ & locusts/falsa acácia & $\begin{array}{l}\text { Endemic of North America } \\
\text { and northern Mexico. Robinia } \\
\text { pseudoacacia was introduced in the } \\
\text { seventeenth century in Europe for } \\
\text { ornamental and medicinal purposes } \\
\text { and for soil stabilization, becoming } \\
\text { invasive in sunny locations and } \\
\text { disturbed areas of Iberian countries, } \\
\text { France, Greece, Hungary, Germany, } \\
\text { Netherlands, United Kingdom and } \\
\text { Cyprus. It has also become invasive } \\
\text { in Asia (Israel, Turkey), South Africa, } \\
\text { South America (Argentina), Australia } \\
\text { and New Zealand. It is a cultivated } \\
\text { species in China. }\end{array}$ & GR3 & $\begin{array}{c}\text { Only Robinia } \\
\text { ferruginea Kunth is } \\
\text { native in Brazil. }\end{array}$ \\
\hline
\end{tabular}

Lotus corniculatus (Fabaceae)

\section{Trifolium}

incarnatum

(Fabaceae)

Trifolium pratense (Fabaceae)

Trifolium repens (Fabaceae) herb

bird's-foot trefoil/ cornichão

crimson clover, italian clover /

herb trevo-encarnado erva-do-amor, trevo-vermelho

herb

red clover/trevo vermelho

herb white clover/trevo branco

\section{Native of temperate grassland in Eurasia and North Africa.}

Native to southwestern Europe, but widely used as fodder for cattle in various parts of the world, primarily in North America and Australia.

Native to Europe, western Asia and northwest Africa. Widely used as fodder for cattle in various parts of the world.

Natural distribution in Europe, North Africa and West Asia. It was introduced in most temperate regions as fodder production plant and as to enhancing natural and semi natural pasture lands, being common nowadays in most of North America and New Zealand.
GR3, GR4, Exotic. Used as a GR5 forage legume in southern Brazil.

GR5, GR9, Exotic. Cultivated GR10 for livestock feed in southern Brazil.

Exotic. Cultivated

GR3, GR4 for livestock feed in southern Brazil.

In Brazil there is the native $T$.

GR9 argentinense Speg. whose pollen is similar. 


\begin{tabular}{|c|c|c|c|c|c|}
\hline Pollen types & $\begin{array}{l}\text { Life } \\
\text { form }\end{array}$ & $\begin{array}{l}\text { English and } \\
\text { Portuguese } \\
\text { vernacular names } \\
\text { (when available) }\end{array}$ & $\begin{array}{l}\text { Geographical origin and economical } \\
\text { use of the correspondent plants }\end{array}$ & $\begin{array}{l}\text { Presence on } \\
\text { samples }\end{array}$ & Ocurrence in Brazil \\
\hline $\begin{array}{l}\text { Vicia faba } \\
\text { (Fabaceae) }\end{array}$ & herb & $\begin{array}{l}\text { broad bean, fava } \\
\text { bean, bell bean, } \\
\text { horse bean /fava, } \\
\text { feijão-fava, fava } \\
\text { cavalinha }\end{array}$ & $\begin{array}{l}\text { The origin of this vegetable is } \\
\text { undetermined, but has been cultivated } \\
\text { in the Middle East in the last } 8000 \\
\text { years before spreading to Western } \\
\text { Europe. Great importance in Europe, } \\
\text { particularly in Italy. }\end{array}$ & GR4 & $\begin{array}{l}\text { Exotic. In Brazil it is } \\
\text { rarely cultivated. }\end{array}$ \\
\hline $\begin{array}{l}\text { Castanea } \\
\text { (Fagaceae) }\end{array}$ & tree & $\begin{array}{l}\text { chestnut/ } \\
\text { castanheira }\end{array}$ & $\begin{array}{l}\text { Native to temperate Northern } \\
\text { Hemisphere region (North America, } \\
\text { Asia and Europe), but it is cultivated } \\
\text { in many parts of the world. }\end{array}$ & $\begin{array}{l}\text { GR1, GR2, } \\
\text { GR3, } \\
\text { GR4, GR5, } \\
\text { GR8, GR9, } \\
\text { GR10 }\end{array}$ & $\begin{array}{l}\text { Exotic. In Brazil it is } \\
\text { rarely cultivated. }\end{array}$ \\
\hline $\begin{array}{l}\text { Quercus } \\
\text { (Fagaceae) }\end{array}$ & tree & oak/carvalho & $\begin{array}{l}\text { Native to Northern Hemisphere, and } \\
\text { includes deciduous and evergreen } \\
\text { species distributed from colder } \\
\text { temperate regions to the tropical } \\
\text { latitudes of Eurasia and the Americas. }\end{array}$ & $\begin{array}{l}\text { GR4, GR9, } \\
\quad \text { GR10 }\end{array}$ & $\begin{array}{l}\text { Exotic. In Brazil, } \\
\text { the cultivation } \\
\text { is restricted to } \\
\text { Paraná State, } \\
\text { for the "shitake" } \\
\text { production. }\end{array}$ \\
\hline $\begin{array}{l}\text { Hypecoum } \\
\text { (Fumariaceae) }\end{array}$ & herb & & $\begin{array}{l}\text { Native to the Northern Hemisphere } \\
\text { and Southern Africa. }\end{array}$ & GR5 & Exotic. \\
\hline $\begin{array}{l}\text { Salvia } \\
\text { (Lamiaceae) }\end{array}$ & $\begin{array}{l}\text { herb, } \\
\text { shrub }\end{array}$ & $\begin{array}{l}\text { common sage, } \\
\text { mint/sálvia, menta }\end{array}$ & $\begin{array}{l}\text { Distributed throughout the Old World } \\
\text { and the Americas, with three distinct } \\
\text { regions of diversity: Central and } \\
\text { South America, Central Asia and the } \\
\text { Mediterranean and East Asia. }\end{array}$ & GR8 & $\begin{array}{c}\text { Several native } \\
\text { species in Brazil. } \\
\text { Some species are } \\
\text { used as a condiment, } \\
\text { medicinal herb and } \\
\text { as ornamental plants } \\
\text { worldwide, also in } \\
\text { Brazil. }\end{array}$ \\
\hline Vitex (Lamiaceae) & $\begin{array}{l}\text { tree, } \\
\text { shrub }\end{array}$ & $\begin{array}{l}\text { chastetree/árvore } \\
\text { da castidade, pau } \\
\text { de angola }\end{array}$ & $\begin{array}{l}\text { They are native to the tropics and } \\
\text { subtropics, with some species in } \\
\text { temperate Eurasia. }\end{array}$ & GR4 & $\begin{array}{l}\text { Several native } \\
\text { species in Brazil. }\end{array}$ \\
\hline Tilia (Malvaceae) & tree & $\begin{array}{l}\text { lime trees, linden/ } \\
\text { tília }\end{array}$ & $\begin{array}{l}\text { Native to Northern Hemisphere, } \\
\text { naturally occurring in temperate } \\
\text { regions of Eurasia and North America. } \\
\text { It is used for ornamental purposes } \\
\text { and for infusions and medicine. It is } \\
\text { pollinated by insects. Its greatest use } \\
\text { is in beekeeping because it provides } \\
\text { unifloral honey of excellent quality. }\end{array}$ & GR1, GR3 & Exotic. \\
\hline $\begin{array}{l}\text { Ligustrum } \\
\text { (Oleaceae) }\end{array}$ & $\begin{array}{l}\text { tree, } \\
\text { shub }\end{array}$ & privet/ligustro & $\begin{array}{c}\text { Native to Europe, North Africa, } \\
\text { Asia and Australia. Some species } \\
\text { have become widely naturalized } \\
\text { or invasive. Its pollen produces } \\
\text { respiratory allergies. }\end{array}$ & GR9 & $\begin{array}{l}\text { Three species are } \\
\text { exotic naturalized } \\
\text { and cultivated for } \\
\text { ornamental purposes } \\
\text { in Brazil. }\end{array}$ \\
\hline
\end{tabular}


Table 2 (continuation)

\begin{tabular}{|c|c|c|c|c|}
\hline Pollen types & $\begin{array}{l}\text { Life } \\
\text { form }\end{array}$ & $\begin{array}{c}\text { English and } \\
\text { Portuguese } \\
\text { vernacular names } \\
\text { (when available) }\end{array}$ & $\begin{array}{l}\text { Geographical origin and economical } \\
\text { use of the correspondent plants }\end{array}$ & $\begin{array}{l}\text { Presence on } \\
\text { samples }\end{array}$ \\
\hline
\end{tabular}

Fagopyrum

(Polygonaceae)

herb

buckwheat/trigo

sarraceno, trigomourisco

Native to Central Asia and Northern Europe.

docks, common

Rumex

(Polygonaceae)

herb

sorrel/labaça,

cata-cruz, regaloda-horta

speedwell, bird's eye, gypsyweed/

Veronica

(Plantaginaceae)

herb

verônica-dos-

campos, morrião-

da-água, verônicada-pérsia

marsh-marigold,

Caltha

(Ranunculaceae)

Thalictrum

(Ranunculaceae)

herb

kingcup/calta,

malmequer dos brejos

meadow-rue/

ruibarbo-dos-

pobres, taliestro

plums, cherries,

peaches, apricots,

\section{Prunus}

(Rosaceae)

tree,

shrub

etc/ameixeiras,

cerejeiras,

pessegueiros,

damasqueiros, etc

raspberries,

herb, blackberries,

Rubus (Rosaceae) shrub, dewberries, etc/

climber framboesa, amora, mirtilo, etc

false buttonweed/

Borreria

(Rubiaceae) Hemisphere. It is widely used in land herb, vassourinha,

shrub vassourinha de botão, etc
Cosmopolitan dispersion, although the largest concentration is in the temperate regions of the Northern cover and medicine as an expectorant.

Occurs in moist environments in temperate and cold regions of both northern and southern hemispheres.

Used in homeopathic medicines.

Native to temperate regions.

By all temperate regions of the Northern Hemisphere.

Native to the Americas, Europe, Africa and Asia. Use for consumption and for medicinal properties.

In tropical and subtropical regions.

His greatest diversity is found in

the Americas, followed by Africa,

Australia and Asia.
GR1, GR3

Exotic

Few native species in Brazil.

GR9

Exotic. Cultivated worldwide for

human and animal

consumption, and

as an ornamental

plant. Its cultivation

is restricted to the

southern of Brazil.

Few native species in Brazil. Several

species have been

introduced almost

everywhere to be

edible, providing

tannin and by its

purgative qualities.

GR1, GR5,

Few species are exotic naturalized GR8, GR9, GR10

in southeastern and southern of Brazil.

GR1, GR3, Many species are

GR4, GR5 cultivated worldwide for food purposes and ornamental value, also in Brazil. Few native species in Brazil. Many species are cultivated worldwide for food purposes, also in Brazil.

Several native species in Brazil. 
Table 2 (continuation)

\begin{tabular}{lcccc}
\hline Pollen types & $\begin{array}{c}\text { Life } \\
\text { form }\end{array}$ & $\begin{array}{c}\text { English and } \\
\text { Portuguese } \\
\text { vernacular names } \\
\text { (when available) }\end{array}$ & $\begin{array}{c}\text { Geographical origin and economical } \\
\text { use of the correspondent plants }\end{array}$ & $\begin{array}{c}\text { Presence on } \\
\text { samples }\end{array}$ \\
\hline
\end{tabular}

\begin{tabular}{|c|c|c|c|c|c|}
\hline Salix (Salicaceae) & $\begin{array}{l}\text { herb, } \\
\text { shrub, } \\
\text { tree }\end{array}$ & $\begin{array}{l}\text { willows/salgueiro, } \\
\text { chorão }\end{array}$ & $\begin{array}{l}\text { Mainly inhabit moist soils of the cold } \\
\text { and temperate regions of the Northern } \\
\text { Hemisphere. The trees are grown in } \\
\text { various parts of the world: Australia, } \\
\text { were considered invasive weed pests; } \\
\text { in China, it has been grown in order to } \\
\text { protect agricultural areas, serving as a } \\
\text { barrier to the desert winds. Its bark is } \\
\text { used in the manufacture of wicker and } \\
\text { the production of aspirin. }\end{array}$ & $\begin{array}{l}\text { GR4, GR5, } \\
\text { GR9, GR10 }\end{array}$ & $\begin{array}{l}\text { Only two native } \\
\text { species in Brazil. } \\
\text { Salix babylonica L. } \\
\text { was introduced as } \\
\text { ornamental plant in } \\
\text { the southern States } \\
\text { of Brazil. }\end{array}$ \\
\hline $\begin{array}{l}\text { Acer negundo } \\
\text { (Sapindaceae) }\end{array}$ & tree & $\begin{array}{l}\text { box elder, boxelder } \\
\text { maple, ash-leaved } \\
\text { maple, maple ash / } \\
\text { bôrdo }\end{array}$ & $\begin{array}{l}\text { North and Central America, occurring } \\
\text { naturally from Canada to Guatemala. } \\
\text { It was introduced in Europe, China } \\
\text { and Australia, becoming invasive. In } \\
\text { Australia is listed as a pest. }\end{array}$ & $\begin{array}{l}\text { GR3, GR5, } \\
\text { GR9, GR10 }\end{array}$ & Exotic. \\
\hline $\begin{array}{l}\text { Saxifraga } \\
\text { (Saxifragaceae) }\end{array}$ & herb & $\begin{array}{l}\text { saxifrages, } \\
\text { rockfoils/coroa do } \\
\text { rei, manto dourado, } \\
\text { saxífraga }\end{array}$ & $\begin{array}{l}\text { They are typical inhabitants of the } \\
\text { Arctic-alpine ecosystems and subarctic } \\
\text { in glacial habitat, and are almost } \\
\text { never found outside the temperate } \\
\text { parts of the Northern Hemisphere } \\
\text { (Europe, Asia and North Africa). Used } \\
\text { worldwide as an ornamental plant and } \\
\text { with medicinal purpose. }\end{array}$ & GR3 & Exotic. \\
\hline $\begin{array}{l}\text { Solanum } \\
\text { (Solanaceae) }\end{array}$ & $\begin{array}{l}\text { herb, } \\
\text { shrub }\end{array}$ & $\begin{array}{c}\text { potato, aubergine, } \\
\text { pepper, tomato/ } \\
\text { batata, berinjela, } \\
\text { pimenta, tomate }\end{array}$ & $\begin{array}{c}\text { Cultivated in various parts of the } \\
\text { world. }\end{array}$ & $\begin{array}{l}\text { GR1, GR3, } \\
\text { GR4 }\end{array}$ & $\begin{array}{l}\text { Several native } \\
\text { species in Brazil. } \\
\text { Several species are } \\
\text { cultivated worldwide } \\
\text { to food purposes, } \\
\text { also in Brazil. }\end{array}$ \\
\hline Ulmus (Ulmaceae) & tree & elms/olmo & $\begin{array}{l}\text { Constitute natural forests in temperate } \\
\text { regions of Eurasia and North America, } \\
\text { but with tropical distribution in Indonesia. } \\
\text { It is cropped for various purposes: its } \\
\text { wood is used in carpentry and furniture in } \\
\text { the shipbuilding industry; in Australasia } \\
\text { is used with ornamental purposes, both in } \\
\text { parks and in bonsai; its foliage are widely } \\
\text { used in animal feed in Asia; as a source } \\
\text { of biomass in Europe and for medicinal } \\
\text { purposes. }\end{array}$ & $\begin{array}{l}\text { GR1, GR3, } \\
\text { GR4 }\end{array}$ & Exotic. \\
\hline $\begin{array}{l}\text { Parthenocissus } \\
\text { (Vitaceae) }\end{array}$ & climber & $\begin{array}{l}\text { virginia creeper, } \\
\text { five-finger, thicket } \\
\text { creeper, grape ivy/ } \\
\text { hera }\end{array}$ & $\begin{array}{l}\text { Native to the Himalayas, East Asia } \\
\text { and North America. Often used as } \\
\text { ornamental plants in Europe and } \\
\text { elsewhere, including in the tropics. }\end{array}$ & $\begin{array}{l}\text { GR1, GR3, } \\
\text { GR5, GR8, } \\
\text { GR9, GR10 }\end{array}$ & $\begin{array}{l}\text { Exotic. Few species } \\
\text { are cultivated } \\
\text { worldwide to } \\
\text { ornamental } \\
\text { purposes, also in } \\
\text { Brazil. }\end{array}$ \\
\hline
\end{tabular}


Acer negundo, Betula, Cistus, Ligustrum, Myosotis, Nyssa, Prunus, Quercus, Salix, Trifolium incarnatum, Zea mays, some Asteraceae and Fabaceae and some unidentified pollen types (table 1). Many of these are indicators of the Northern Hemisphere origin of the samples (table 2).

Some pollen types that had less importance in the PCA ordination of the samples, but that can be good indicators of a Northern Hemisphere origin were Larix, Rumex, Sambucus, Tilia and Ulmus (figure 1).

The pollen types Nyssa and Mimosa pudica are good indicators of phytogeographical origins recovered in the present study. The observations of these pollen types demonstrate an Asian or North American origin as opposed to a European origin (Piana et al. 2006, Dimou et al. 2013).

The pollen detected from Nyssa ("tupelo") may be explained because trees of this genus are highly nectariferous and are valued by beekeepers due to the high quality of honey produced by bees that explore them. Nevertheless, pollen from species of this genus are generally underrepresented in honey samples (Lieux 1978). Some of the Nyssa species are native to eastern North America to Central America. Other species also occur naturally in Southeast Asia from China to the southeastern Himalaya Mountains, but they are lacking in Europe. The pollen grains of these two groups can be differentiated through scanning electron microscopy by the presence of tiny elongated sexine elements (rugulae) in the margins of the colpori of the Asian species, while the American ones do not show them (Göschl 2008). In light microscopy, it is not easy to distinguish them. This pollen type was found in samples GR1, GR5, GR9 and GR10 (table 2). Therefore, according to the total pollen spectrum of each sample, this pollen type can be an excellent indicator of the Asian or Northern American phytogeographical origin of royal jelly.

The presence of the Mimosa pudica pollen grains indicates tropical origin. This species is native to Central and South America, but because it is an invasive weed, it now also occurs in Africa, North America, Asia and Australia.

According to Piana et al. (2006), Mimosa pudica is one of the pollen types that occur in Asian royal jelly (specifically from Vietnam) but is absent in 28 samples from Italy, as well as in 82 royal jelly samples from Greece analyzed by Dimou et al. (2013). In the samples sold in São Paulo, this pollen type was only found in GR8, as an Important minor pollen (I) (table 1). This sample had $97.33 \%$ similarity with the group formed by samples GR1, GR5, GR9, and GR10, which are characterized by the presence of Nyssa pollen type and probably originated from Asia or North America (figure 2).

Sample GR4, with Apiaceae, Brassicaceae, Fagopyrum esculentum, Helianthemum, Lotus corniculatus, Quercus, Salix, Taraxacum, Trifolium, Vicia faba and Vitex, was more similar to royal jelly from China (figure 3), based on seven samples analyzed by Piana et al. (2006). Several of these pollen types were also reported in Chinese honey by Song et al. (2012).

Among the frequent pollen types in sample GR4, Quercus and Fagopyrum esculentum occur in Brazil. Quercus is restricted to Paraná State, used for the cultivation of Shiitake mushrooms on oak logs (Bett \& Perondi 2011). Buckwheat (Fagopyrum esculentum) was introduced in the south of the country during the 1920s by the Slavic immigrants (Gorgen 2013). However, the pollen spectrum of sample GR4 has no similarity with the pollen spectra of Brazilian

Table 3. Pearson and Kendall correlation coefficients for pollen grains counting variables of the first and the second axis of PCA ordination in eight royal jelly samples with Paenibacillus larvae spores purchased in São Paulo State, Brazil.

\begin{tabular}{lcc}
\hline Variables/samples & \multicolumn{2}{c}{ (Principal components) } \\
\hline & Axis 1 & Axis 2 \\
GR1 & -0.2926 & -0.2179 \\
GR2 & -0.1359 & -0.0942 \\
GR3 & -0.0685 & -0.3167 \\
GR4 & -0.1162 & -0.6241 \\
GR5 & -0.4369 & -0.3575 \\
GR8 & -0.2479 & -0.0338 \\
GR9 & -0.6814 & 0.5587 \\
GR10 & -0.4013 & -0.1131 \\
\hline
\end{tabular}


royal jelly, honey, or bee pollen (Barth 2004-2005, Morgado \& Barth 2011). Therefore, the probable phytogeographical origin of this sample is Asia.

According to the PCA analysis, sample GR4, typically Asian, was similar to sample GR3. They were grouped based on the presence of Castanea, Brassicaceae, Daucus, Lotus corniculatus, Trifolium pratense, Poaceae, Prunus, Solanum and Ulmus. These pollen types are common in honey from Europe, Asia and North America (Lieux 1975-1977-1978, Louveaux 1970, Song et al. 2012).

The pollen spectra showing the presence of cultivated plants Brassicaceae, Castanea, Daucus and Trifolium pratense in samples GR3 and GR4 were also reported by Diaz-Losada et al. (1998) in Italian honey. These authors stated that the location of the apiary near a temperate forest is reflected in Italian honey by the presence of Quercus and Ulmus pollen grains or by the abundance of pollen from prairie herbs such as Trifolium pratense and Lamiaceae or also near areas of moist soil due to the presence of pollen of plants adapted to that environment, e.g., Salix.

The royal jelly sample GR2 had a high percentage of pollen of cultivated plants (Brassicaceae and Castanea), similar to many others, but it was the only one with pollen of several species of cultivated plants as celery (Apium, Apiaceae) and Pleurospermum (Apiaceae), two pollen types of Fabaceae (Trifolium and Fabaceae 2), as well as Primulaceae, a family with several ornamental herbaceous plant species widely cultivated around the world. This sample had $88.42 \%$ similarity with the group formed by samples with pollen of $N y s s a$ (GR1, GR5, GR9 and GR10) and Mimosa pudica (GR8) (figure 2), supposedly Asian or North American. As pointed out previously, these pollen types do not occur in European royal jelly.

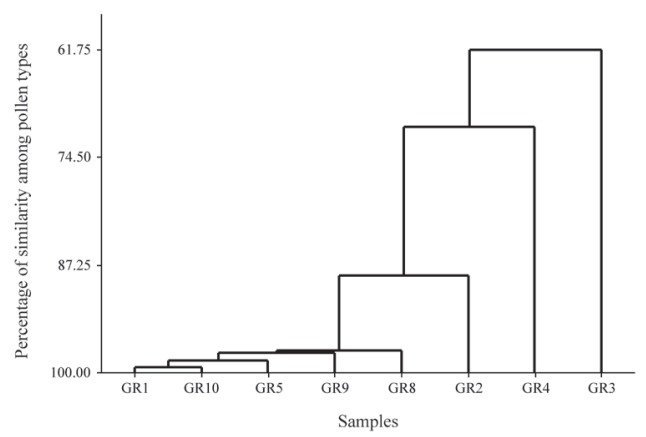

Figure 2. Dendrogram of similarity among the eight royal jelly samples with Paenibacillus larvae spores purchased in São Paulo State, Brazil.
The set with various pollen grains of exotic plants in the samples was similar to the group of European and Chinese royal jelly having $49.54 \%$ similarity with those of Brazilian origin (figures 3-12). This percentage was due to the presence of seven pollen types (Amaranthaceae/Chenopodiaceae, Borreria, Brassicaceae, Mimosa pudica/M. scabrella, Poaceae, Senecio and Solanum) reported in the Brazilian samples analyzed by Barth (2005) and by Morgado and Barth (2011) as well as in some of the samples analyzed in the present study.

Palynological evidence indicates that royal jelly samples contaminated with spores of P. larvae are sold in São Paulo State as Brazilian products, however, they were produced in the Northern Hemisphere. The fact that royal jelly samples from Europe analyzed by other authors have been found similar to those from China, due to the presence of some pollen types, suggests that palynology alone cannot accurately identify the continent or country of origin. No scientific specialty (plant anatomy, palynology, physicochemical) alone can solve problems of the origin of bee products and illegal imports of bee products. Thus, only field observations of bees' visits to flowers cannot define the botanical origin of the floral resources used by bees. Beekeepers' empirical observations should be followed up by physicochemical, anatomical and palynological analyses of bee products, as these analyses broaden the knowledge about bee visits to flowers. In order to be sure of the geographical origin of these contaminated royal jelly batches, public inspection agents should audit in the warehouses that packed the royal jelly about the origin of the contaminated product that is being marketed in São Paulo.

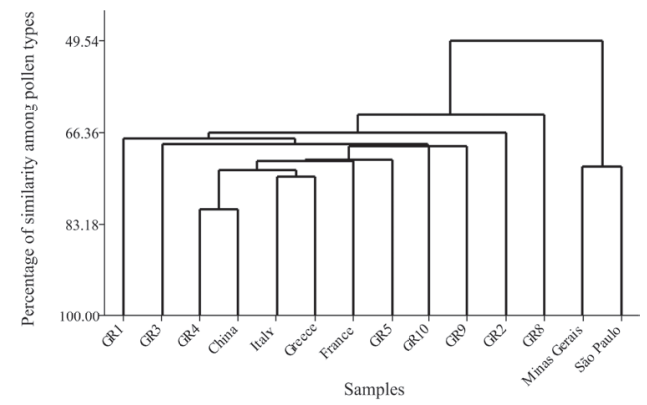

Figure 3. Dendrogram of similarity among the eight royal jelly samples with Paenibacillus larvae spores purchased in São Paulo State (Brazil) and those ones from Minas Gerais and São Paulo States (Brazil), China, France, Greece and Italy. 

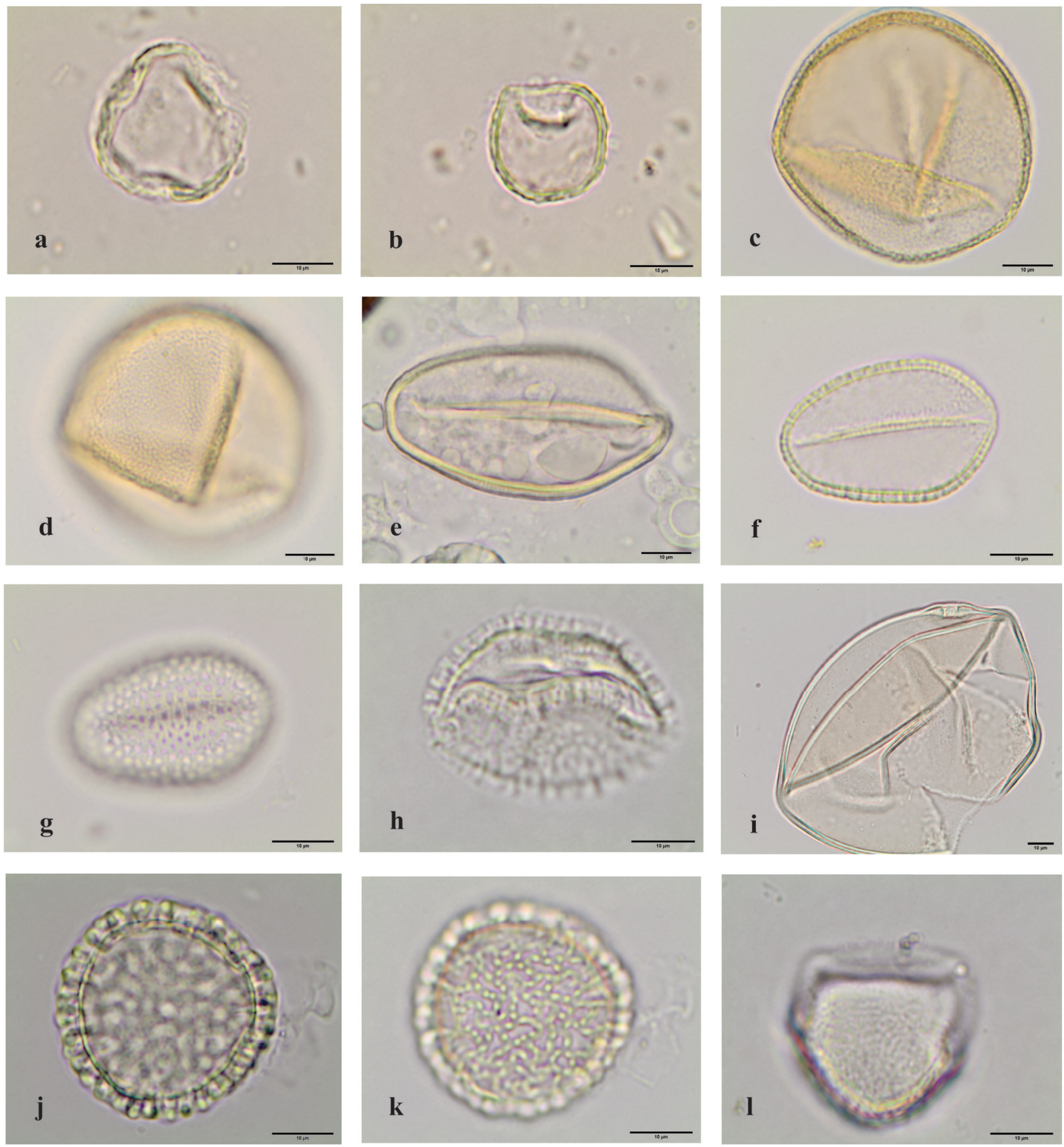

Figure 4. Light microscopy photographs of pollen grains observed in the royal jelly samples. a-d. Gymnospermae. a-b. Cupressaceae. c-d. Pinaceae, Larix. e-1. Angiospermae monocotyledons. e. Amaryllidaceae, Allium. f-g. Iridaceae. h. Liliaceae, Lilium. i. Poaceae, Zea mays. j-k. Unknown reticulate monocotyledon. 1. Unknown rugulate monocotyledon. Scale bars: $10 \mu \mathrm{m}$. 

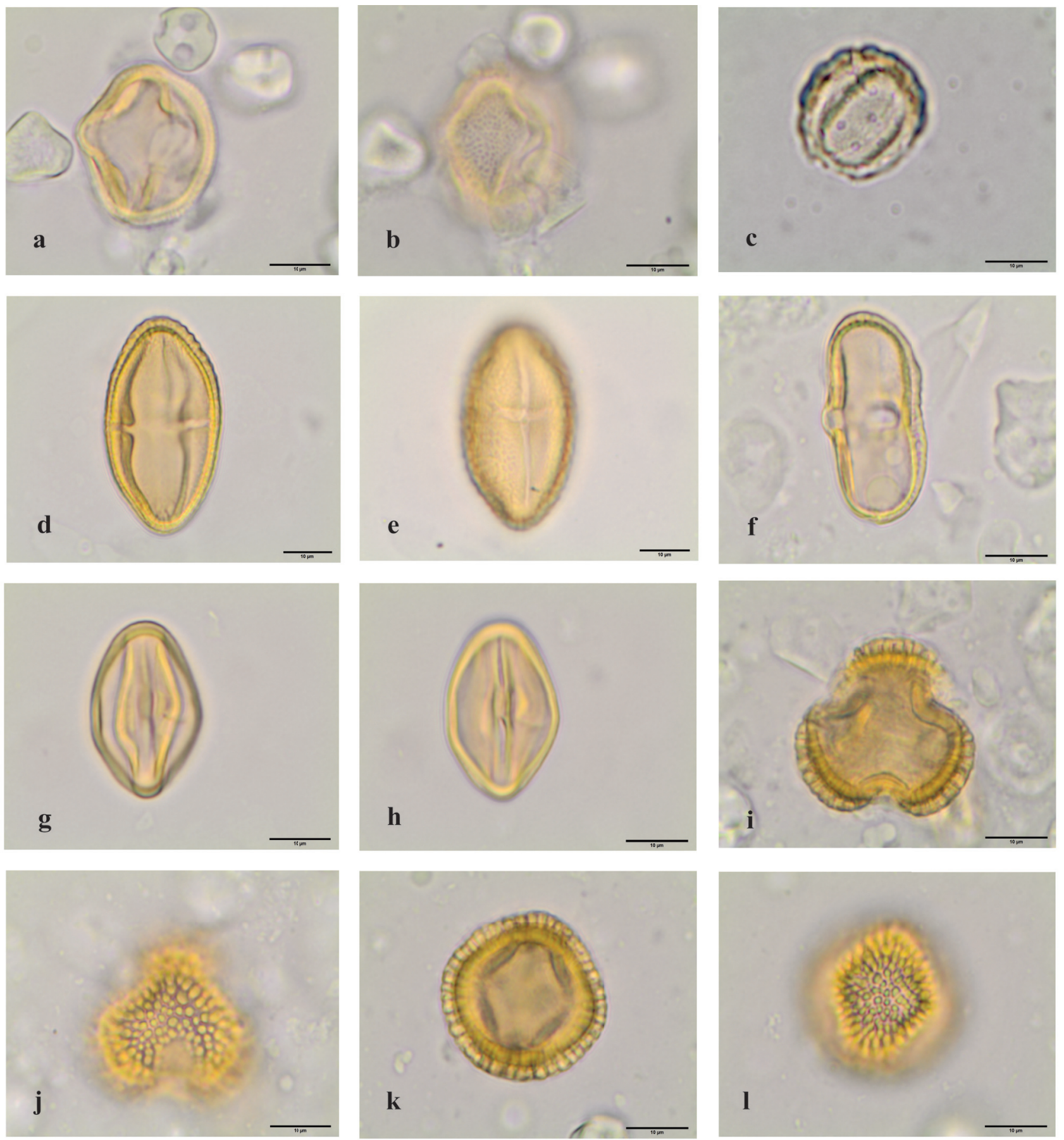

Figure 5. Light microscopy photographs of pollen grains observed in the royal jelly samples. a-l. Angiospermae eudicotyledons. a-b. Adoxaceae, Sabumcus. c. Amaranthaceae. d-h. Apiaceae. d-e. Apium. f. Daucus. g-h. Pleurospermum. i-l. Aquifoliaceae, Ilex. Scale bars: $10 \mu \mathrm{m}$. 

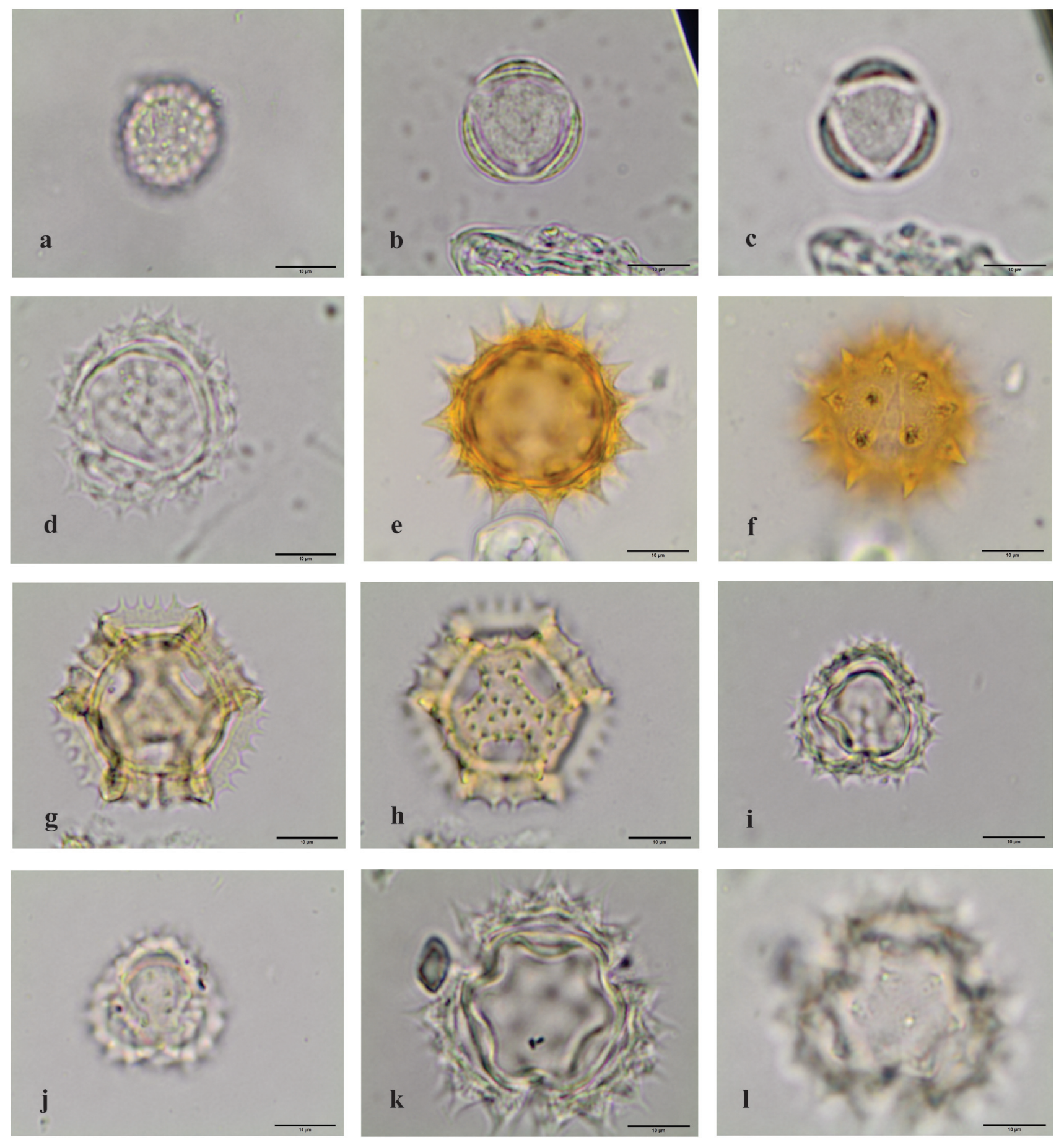

Figure 6. Light microscopy photographs of pollen grains observed in the royal jelly samples. a-1. Angiospermae eudicotyledons, Asteraceae. a. Ambrosia. b-c. Artemisia. d. Cirsium/Carduus. e-f. Senecio. g-h. Taraxacum. i-j. Asteraceae 1. k-l. Asteraceae 3. Scale bars: $10 \mu \mathrm{m}$. 

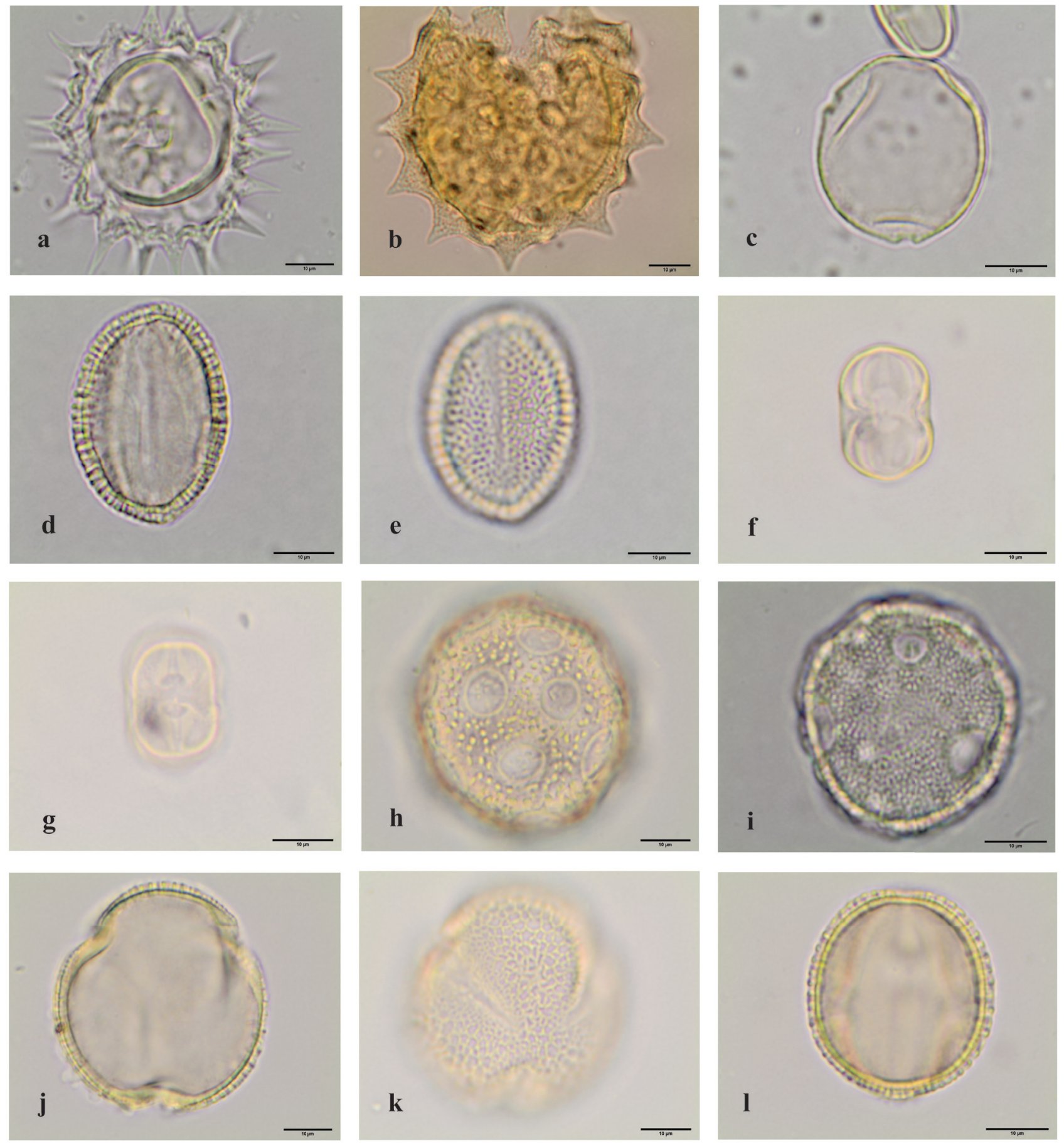

Figure 7. Light microscopy photographs of pollen grains observed in the royal jelly samples. a.l. Angiospermae eudicotyledons. a. Asteraceae 4. b. Asteraceae 5. c. Betulaceae, Betula. d-e. Brassicaceae. f-g. Boraginaceae, Myosotis. h-i. Caryophyllaceae. h. Caryophyllaceae 1. i. Melandrium. j-1 Cistaceae, Cistus. Scale bars: $10 \mu \mathrm{m}$. 

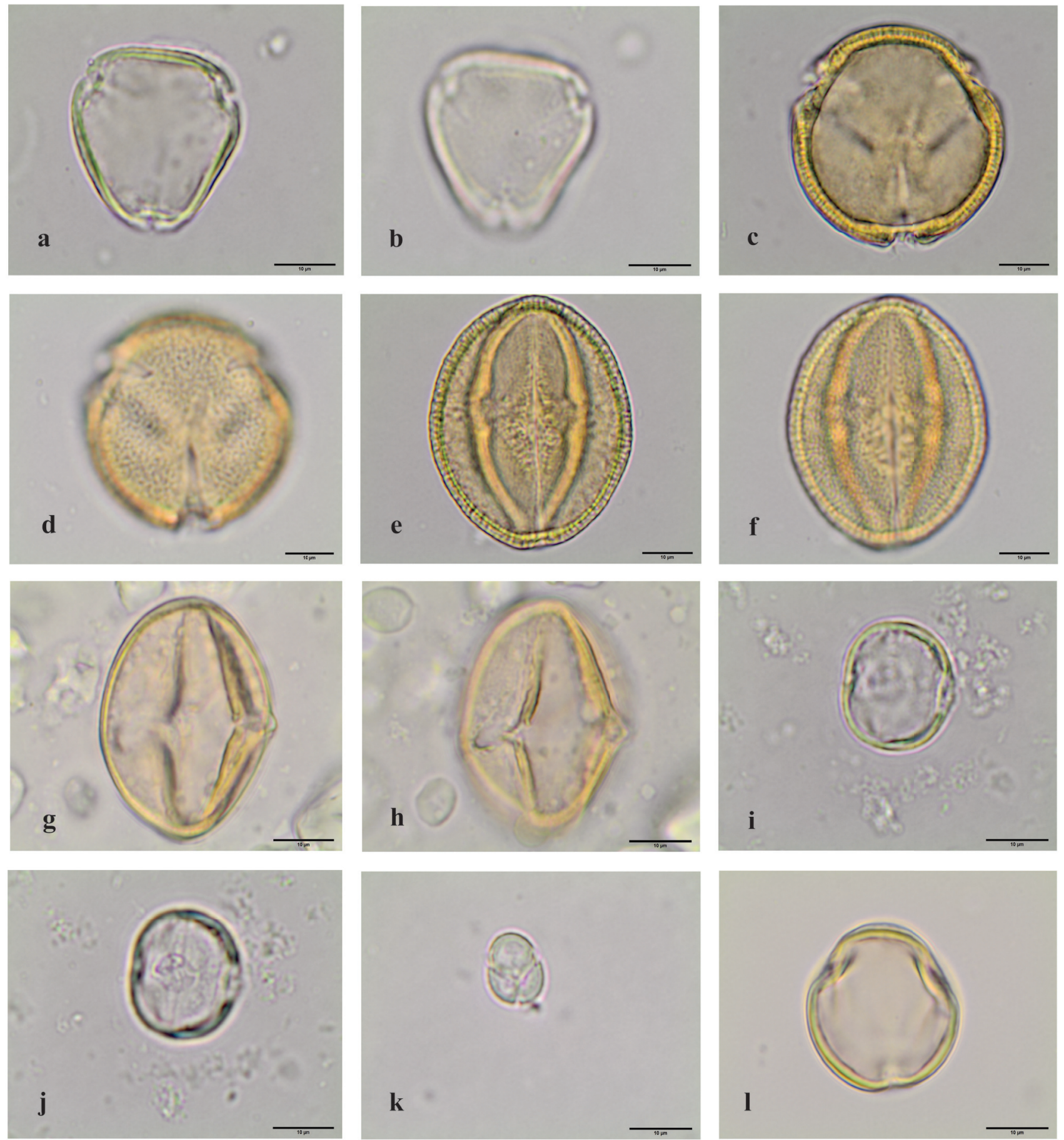

Figure 8. Light microscopy photographs of pollen grains observed in the royal jelly samples. a-l. Angiospermae eudicotyledons. a-b. Cornaceae, Nyssa. c-f. Euphorbiaceae. g-l. Fabaceae. g-h. Cassia. i-j. Lotus corniculatus. k. Mimosa pudica. 1. Robinia. Scale bars: 10 um. 

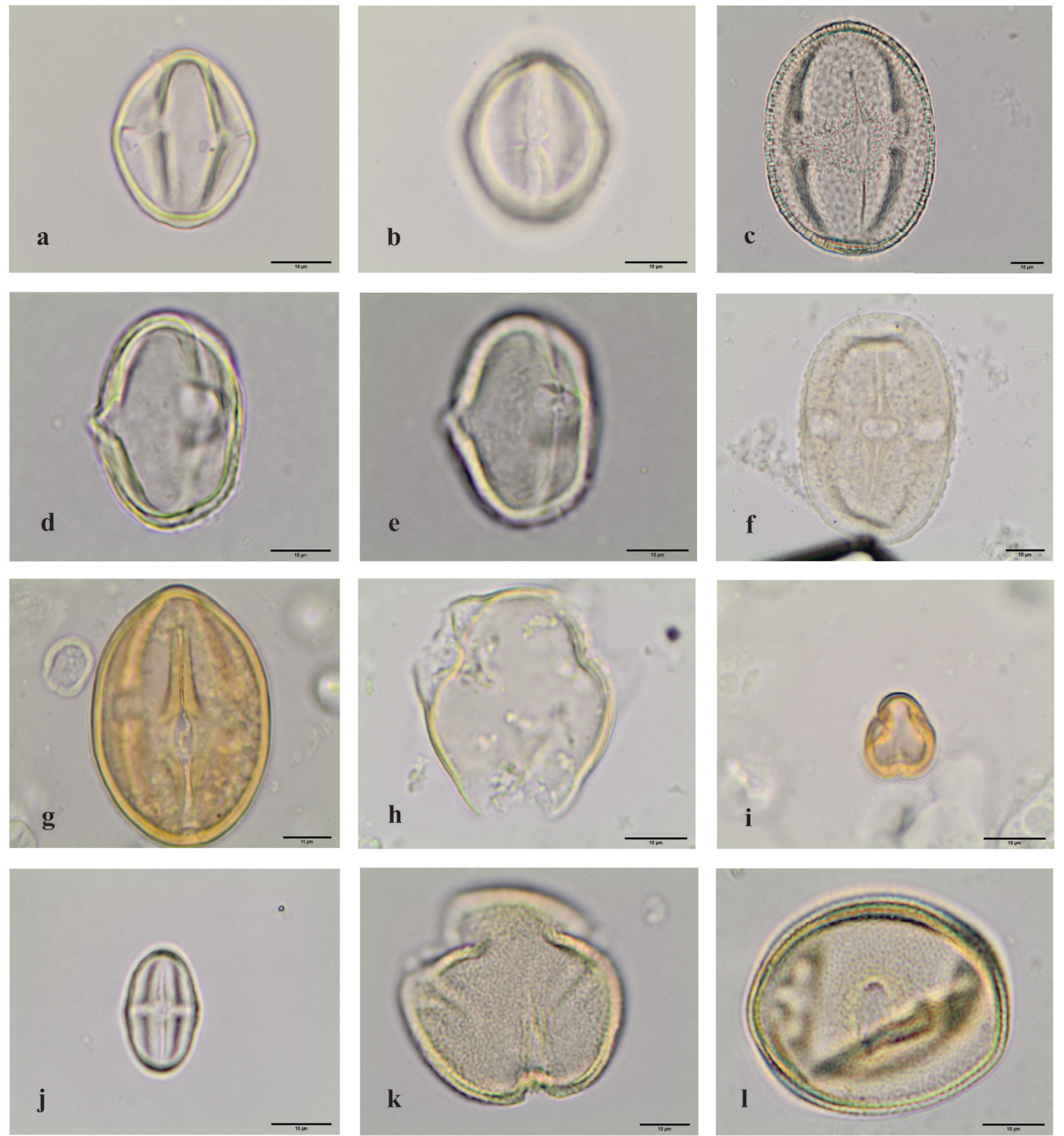

Figure 9. Light microscopy photographs of pollen grains observed in the royal jelly. a-1. Angiospermae eudicotyledons. a-h. Fabaceae. a-b. Robinia. c. Trifolium incarnatum. d-e. Trifolium repens. f. Vicia faba. g. Fabaceae 1. h. Fabaceae 4. i-l. Fagaceae. i-j. Castanea. k-1. Quercus. Scale bars: $10 \mu \mathrm{m}$. 

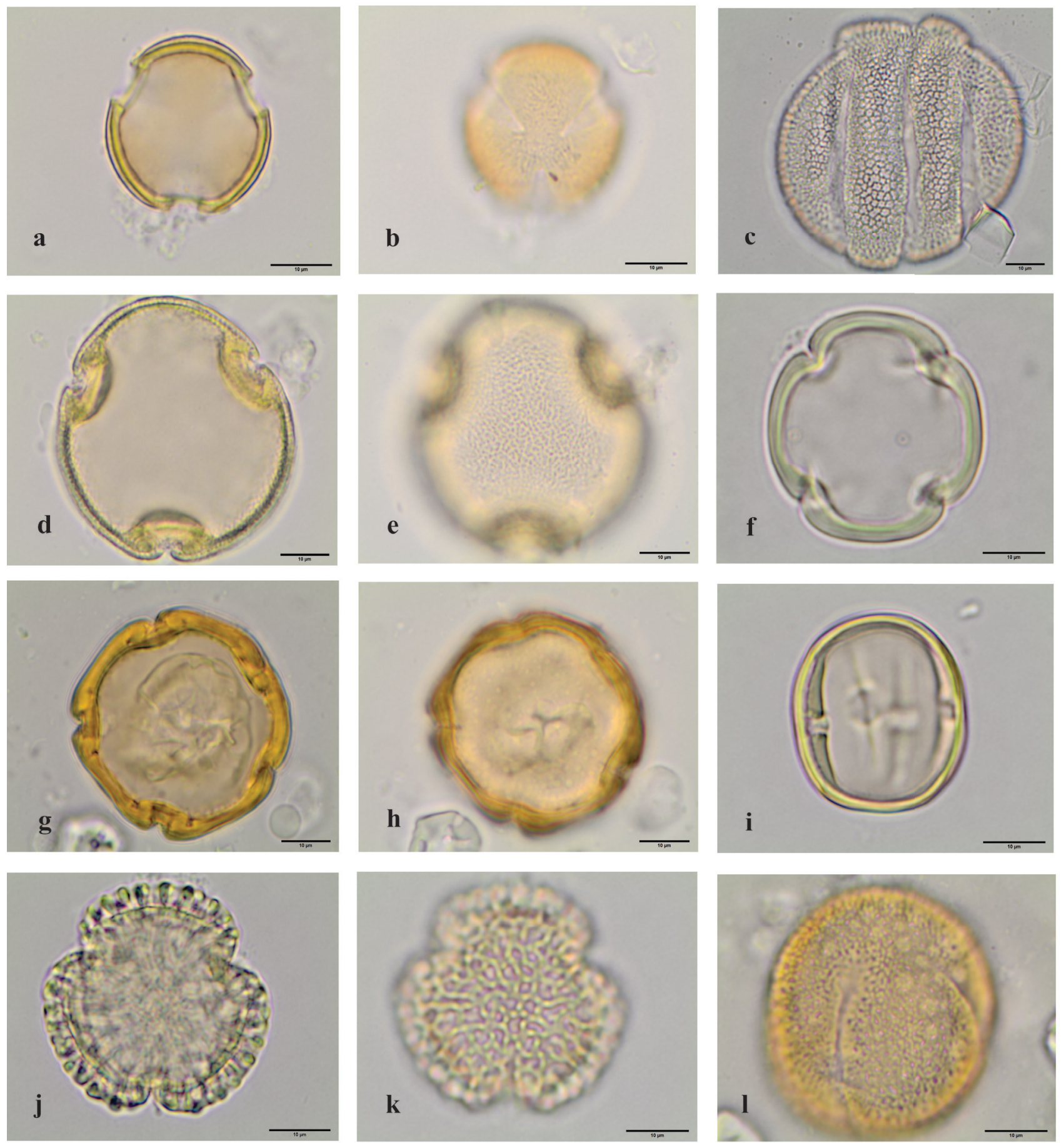

Figure 10. Light microscopy photographs of pollen grains observed in the royal jelly samples. a-1. Angiospermae eudicotyledons. a-b. Gentianaceae. c. Lamiaceae. d-e. Malvaceae, Tilia. f-i. Meliaceae. f. Meliaceae 1. g-h. Meliaceae 2. i. Meliaceae 3. j-k. Oleaceae, Ligustrum. 1. Polygonaceae, Rumex. Scale bars: $10 \mu \mathrm{m}$. 

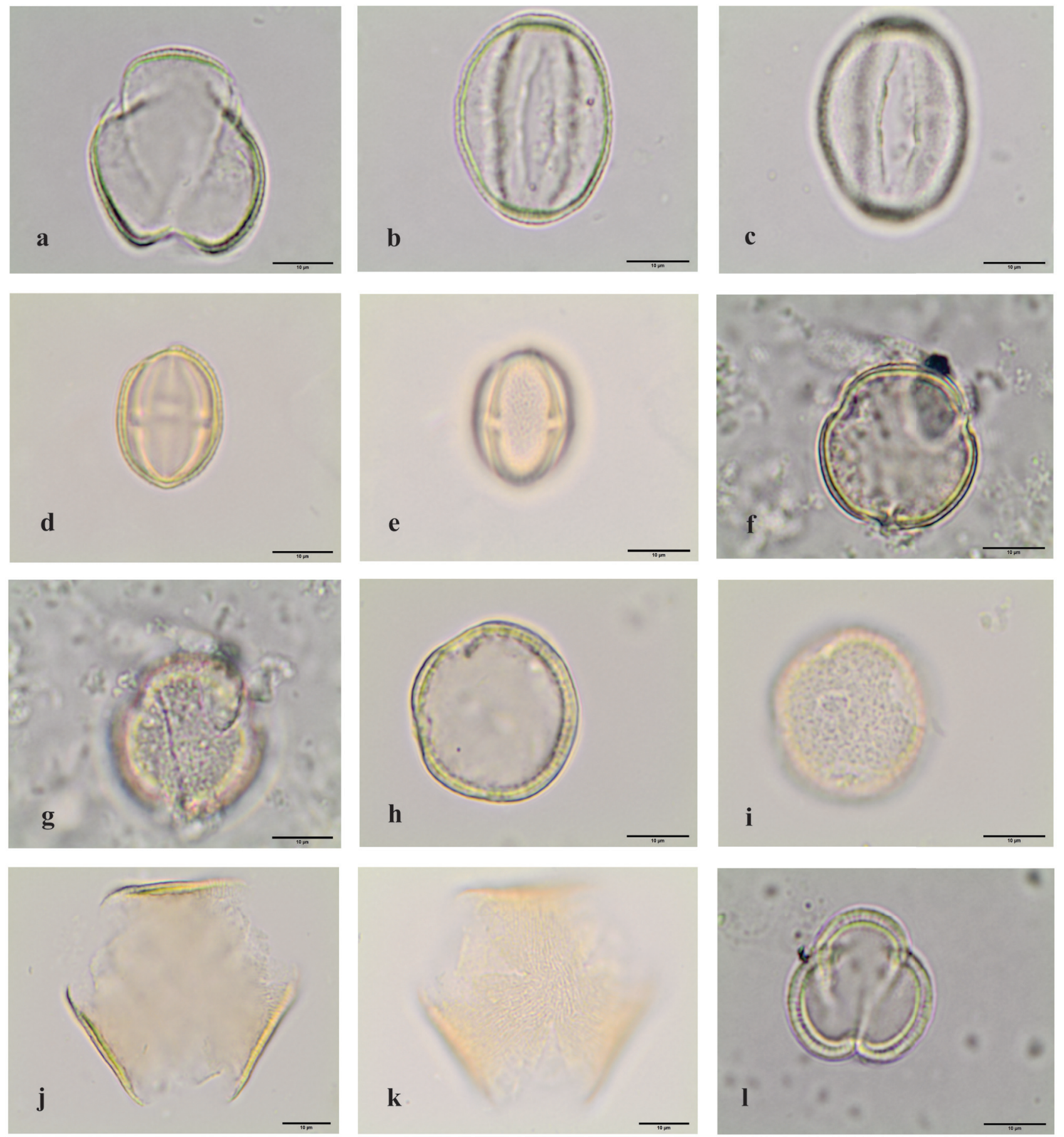

Figure 11. Light microscopy photographs of pollen grains observed in the royal jelly samples. a-1. Angiospermae eudicotyledons. a-c. Plantaginaceae, Veronica. d-e. Primulaceae, f-i. Ranunculaceae. f-g. Caltha. h-i. Thalictrum. j-k. Rosaceae, Prunus. 1. Salicaceae, Salix. Scale bars: $10 \mu \mathrm{m}$. 

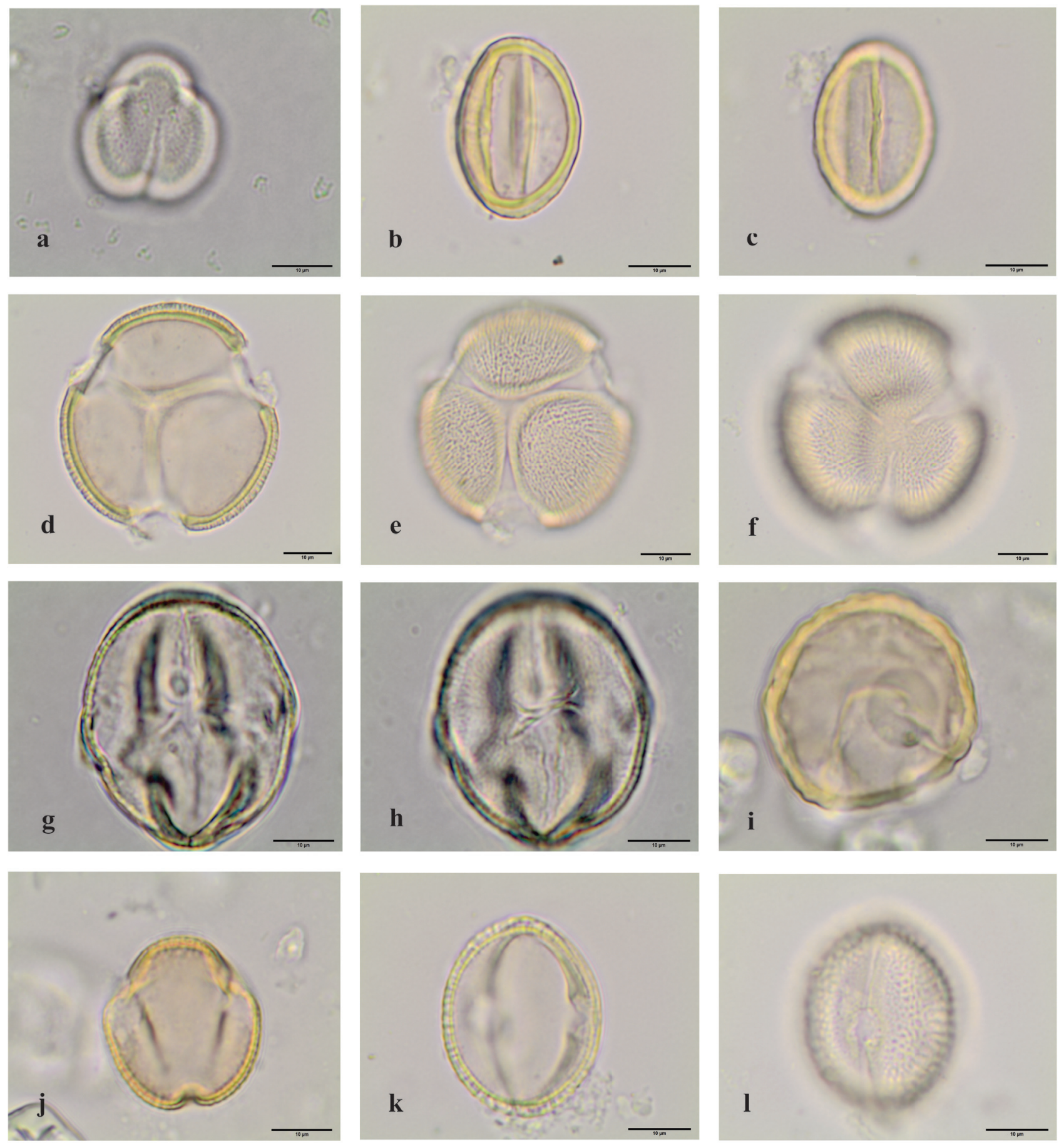

Figure 12. Light microscopy photographs of pollen grains observed in the royal jelly samples. a-1. Angiospermae eudicotyledons. a. Salicaceae, Salix. b-c. Sapindaceae, Acer negundo. d-f. Saxifragaceae, Saxifraga. g-h. Solanaceae. i. Ulmaceae, Ulmus. j-l. Vitaceae, Parthenocissus. Scale bars: $10 \mu \mathrm{m}$. 
The Brazilian Ministry of Agriculture had no records of imported royal jelly from Europe, North America or Asia related to the period of the corresponding lots. Thus, the contaminated lots were probably illegally imported, threatening national beekeepers. As royal jelly production in Brazil is no longer economically viable due to the illicit entry of royal jelly over the past decade from China at low prices, we suggest that the analyzed products are original without the mixture of royal jelly produced locally in Brazil. This is a matter of concern because the dispersion of $P$. larvae spores from imported products without sanitary inspection is associated with the following contamination routes: using of contaminated royal jelly to feed queen larvae; manipulating contaminated products and/or utensils used to handle healthy colonies; using contaminated wax as comb substrate; access of bees to remains of contaminated imported products discarded near apiaries; cross-contamination in warehouses (e.g., pollen dryers, where pollen grains of different origins are dehydrated) and supply of contaminated food supplements to healthy bees during the winter (especially bee pollen).

The possibility of $P$. larvae dispersion and contamination of healthy colonies is aggravated by traditional handling procedures such as transferring wax frames among colonies, using the same utensils in multiple bee hives and transferring colonies among apiaries, as well the natural trophallaxis among bees.

We stress the urgency of regulatory agencies taking appropriate measures at warehouses to verify the origin of the lots of royal jelly marketed and thus detect and avoid the illicit trade, as well as to implement risk analysis to identify critical points of the chain for traceability.

\section{Conclusions}

No royal jelly sample contaminated with Paenibacillus larvae had a pollen spectrum compatible with Brazilian vegetation, showing that the products analyzed were imported. The pollen types identified in the samples indicated probable phytogeographical origin from the Northern Hemisphere, either from Europe, Asia or North America.

By carrying out a palynological analysis, it was observed that the pollen grains in the royal jelly samples are from species occurring in temperate climates, such as boreal forests with conifers and milder climates, for example in the Mediterranean. Pollen grains from forage grasses, as well various crops were observed in the royal jelly samples showing similarity with the samples produced by Apis mellifera bees in most parts of the world. Therefore, these pollen types are not appropriate for the characterization of the phytogeographical origin of royal jelly.

The presence of $P$. larvae spores in bee products from Brazilian apiaries is an unexpected finding because the country is officially considered free from the disease. However, a previous study (molecular analysis) done for pathogen detection in the same samples showed that in São Paulo State royal jelly has spores of this bacterium. The lack of effective control in this commercialization, as proven in this study, can ruin Brazilian beekeeping if this pathogen is spread throughout the country and applied palynology in forensic science is helping in this battle.

Overall, our findings show that palynology is a powerful tool in identifying the phytogeographic origins of royal jelly from the Northern Hemisphere. Although the current legislation does not require bee products to be examined palynologically to verify phytogeographic origins, this analysis can help to control pathogens from spreading. In addition, we show the fragility of actions regarding the control of imported products and thus the urgent need for more effective rules and actions by sanitary authorities.

\section{Acknowledgements}

This work was supported by the São Paulo State Research Foundation (FAPESP) under Grant (number 2012/18802-3). CFPL is researcher fellow of the National Council for Scientific and Technological Development (CNPq) under Grant (number 302766/2016-2). MFM is a researcher fellow of the National Council for Scientific and Technological Development (CNPq). JES is a research fellow of the CNPq and Minas Gerais State Research Foundation (FAPEMIG). CFPL also thanks FAPESP for providing financial support to her participation in the Mediterranean Palynology 2015 Symposium (Process Number 2015/145997). Jane Godwin Coury translated the English manuscript.

\section{Literature cited}

Barth, O.M. 2004. Melissopalynology in Brazil: A review of pollen analysis of honeys, propolis and pollen loads of bee. Scientia Agricola 61: 342-350.

Barth, O.M. 2005. Botanical resources used by Apis mellifera determined by pollen analysis of royal jelly in Minas Gerais, Brazil. Journal of Apicultural Research 44: 78-81.

Bett, C.F. \& Perondi, M.A. 2011. Análise do mercado de cogumelos comestíveis e medicinais: uma prospecção de alternativa de renda para a agricultura familiar na região sudoeste do Paraná. Synergismus scyentifica 6: $1-8$. 
Biondi, C., Bedini, G. \& Felicioli, A. 2003, Gelatina reale: metodologia proposta per la determinazione dell'origine geografica e della qualità. Apitalia 6: 32-37.

Bueno, S.C.S. \& Pio, R. 2014. Castanha tipo portuguesa no Brasil. Revista Brasileira de Fruticultura 36: 16-22.

Chauvin, R. \& Louveaux, J. 1956, Etude macroscopique et microscopique de la gelée royale. L'apiculteur 1956: 33-43.

Chen, Y., Zhao, Y., Hammond, J., Hsu, H., Evans, J.D. \& Feldlaufer, M. 2004. Multiple virus infections in the honey bee and genome divergence of honey bee virus. Journal of Invertebrate Pathology 87: 84-93.

Diaz-Losada, E., Ricciardelli-D'Albore, G. \& Saa-Otero, M.P. 1998. The possible use of honeybee pollen loads in characterising vegetation. Grana 37: 155-163.

Dimou, M., Goras, G. \& Thrasyvoulou, A. 2007. Pollen analysis as a means to determine the geographical origin of royal jelly. Grana 46: 118-122.

Dimou, M., Tananaki, C., Goras, G., Karazafiris, E. \& Thrasyvoulou, A. 2013. Melissopalynological analysis of royal jelly from Greece. Grana 52: 106-112.

Erdtman, G. 1952. Pollen morphology and plant taxonomy. Angiosperms (An introduction to Palynology. I). Almquist \& Wiksell, Stockholm.

Flores, J.M., Spivak, M. \& Gutiérrez, I. 2005. Spores of Ascosphaera apis contained in wax foundation can infect honeybee brood. Veterinary Microbiology 108: 41-144.

Fries, I., Chauzat, M.P., Chen, Y.P., Doublet, V., Genersch, E., Gisder, S., Higes, M., McMahon, D.P., Martín-Hernández, R., Natsopoulou, M., Paxton, R.J., Tanner, G., Webster, T.C. \& Williams, G.R. 2013. Standart methods for Nosema research. Journal of Apicultural Research 52: 1-28.

Funfhaus, A., Poppinga, L. \& Genersch, E. 2013. Identification and characterization of two novel toxins expressed by the lethal honeybee pathogen Paenibacillus larvae, the causative agent of American foulbrood. Environmental Microbiology 15: 2951-2965.

Flora do Brasil 2020 (em construção). 2018. Available in http://floradobrasil.jbrj.gov.br/ (access in 15-III-2018).

Garrido-Bailón, E., Higes, M. \& Martínez-Salvador, A. 2013. The prevalence of the honeybee brood pathogens Ascosphaera apis, Paenibacillus larvae and Melissococcus plutonius in Spanish apiaries determined with a new multiplex PCR assay. Microbial Biotechnology 6: 731-739.

Gochnauer, T.A. \& Corner, J. 1974. Detection and identification of Bacillus larvae in a commercial pollen sample. Journal of Apicultural Research 13: 264-267.

Gorgen, A.V. 2013. Produtividade e qualidade da forragem de milheto (Pennisetum glaucum (L.) R.Br) e de trigo mourisco (Fagopyrum esculentum. Moench) cultivado no Cerrado. Monografia, Universidade de Brasília, Brasília.

Göschl, W. 2008. Beiträge zur Pollenmorphologie ausgewählter rezenter und fossiler Vertreter der Davidiaceae und Nyssaceae. Tese, Magister der Naturwissenschaften, Universität Wien, Viena.
Guimarães-Cestaro, L., Serrão, J.E., Message, D., Martins, M.F. \& Teixeira, E.W. 2016. Simultaneous detection of Nosema spp., Ascosphaera apis and Paenibacillus larvae in honeybee products. Journal of Hymenoptera Research 49: 43-50.

Haiqing, X. 2015. Common Cultivated Pollen Flora of China. China Scientific Book Services. Beijing, China.

Hale, P.J. \& Menapace, D.M. 1980. Effect of time and temperature on the viability of Ascosphaera apis. Journal of Invertebrate Pathology 36: 429-430.

Higes, M., Martín-Hernández, R., Garrido-Bailón, E., García-Palencia, P. \& Meana, A. 2008. Detection of infective Nosema ceranae (Microsporidia) spores in corbicular pollen of forager honeybees. Journal of Invertebrate Pathology 97: 76-78.

Hitchcock, J.D. \& Revell, I.L. 1963. The spread of American foulbrood from pollen trapped from bees' legs. American Bee Journal 103: 220-221.

Hornitzky, M. 2010. Honey bee diseases. Australia and New Zealand Standard Diagnostic Procedure. Available in http://www.agriculture.gov.au/animal/health/ laboratories/procedures/anzsdp/honey-bee-diseases/ (access in 27-III-2018).

Johnson, R. 2010. Honey Bee Colony Collapse Disorder. Available in http://www.fas.org/sgp/crs/misc/RL33938. pdf. (access in 14-III-2018).

Klein, A.M., Vaissière, B.E., Cane, J.H., SteffanDewenter, I., Cunningham, S.A., Kremen, C. \& Tscharntke, T. 2007. Importance of pollinators in changing landscapes for world crops. Proceedings of the Royal Society B: Biological Sciences 274: 303-313.

Lieux, M.H. 1975. Dominant pollen types recovered from commercial Louisiana honeys. Economic Botany 29: 87-96.

Lieux, M.H. 1977. Secondary Pollen Types Characteristic of Louisiana Honeys. Economic Botany 31: 111-119.

Lieux, M.H. 1978. Minor honeybee plants of Louisiana indicated by pollen analysis. Economic Botany 32: 418-432.

Louveaux, J., Maurizio, A. \& Vorwohl, G. 1978. Methods of Melissopalynology. Bee World 59: 139-157.

Louveaux, J. 1970. Atlas photographique d'analyse pollinique des miels. Ministere de L'Agriculture, France.

MAPA. 2006. Nota técnica DSA n ${ }^{\circ} 52 / 2006$. Ocorrência de "Cria Pútrida Americana" no município de Quatro Barras, estado do Paraná-Brasil. Ministry of Agriculture of Brasil, Brasília.

Mccune, B. \& Mefford, M.J. 1999. PC-ORD. Multivariate Analysis of Ecological Data. GlenedenBeach, Oregon, MjM Software.

Message, D., Teixeira, E.W. \& De Jong, D. 2012. Situação da sanidade das abelhas no Brasil. In: V.L. Imperatriz-Fonseca, D.A.L. Canhos, D.A. Alves \& A.M. Saraiva (orgs.). Polinizadores no Brasil: Contribuição e perspectivas para a biodiversidade, uso sustentável, conservação e serviços ambientais. EDUSP, São Paulo, pp. 237-256. 
Morgado, L. \& Barth, O.M. 2011. The detection of pollen in royal jelly of honey bees (Apis mellifera). Journal of ApiProduct and ApiMedical Science 3: 137-139.

OIE - World Organization of Animal Health. 2014. American foulbrood of honeybees. In: Manual of diagnostic tests and vaccines for terrestrial animals. v. 1, section 2.2, Chapter 2.2.2. Available in http:// www.oie.int/fileadmin/Home/fr/Health_standards/ tahm/2.02.02_AMERICAN_FOULBROOD.pdf (access in 18-III-2018).

Pettis, J.S., Lichtenberg, E.M., Andree, M., Stitzinger, J., Rose, R. \& Vanengelsdorp, D. 2013. Crop pollination exposes honey bees to pesticides which alter their susceptibility to the gut pathogen Nosema ceranae. PLoS One 8: e70182.

Piana, M.L., Belligoli, P., Persano Oddo, L. \& Piperno, S. 2006. Pollen analysis of royal jelly: contribution to Analytical methods and characterization. Apiacta 41: 28-43.

Pires, C.S.S., Pereira, F.M., Lopes, M.T.R., Nocelli, R.C.F., Malaspina, O., Pettis, J. \& Teixeira, E.W. 2016. Enfraquecimento e perda de colônias de abelhas no Brasil: há casos de CCD? Pesquisa Agropecuária Brasileira 51: 422-442.

Punt, W. \& Clarke, G.C.S. 1974. The Northwest European Pollen Flora. Review of Palaeobotany and Palynology. Elsevier, New York.

Renner, P., Hrassnigg, N. \& Crailsheim, K. 2003. Trophallaxis between nurse bees and pollen foragers under laboratory conditions in Apis mellifera carnica. Apidologie 34: 492.

Ricciardelli D'Albore, G., Battaglini, M. \& D'Ambrosio, M. 1977. Considerazioni sui pollini della gelatina reale. Annali dell'Istituto Sperimentale per la Zoologia Agraria 5: 203-213.
Ricciardelli-D'Albore, G. \& Battaglini, M. 1978. Origine géographique de la gelée royale. Apidologie 9: 1-17.

Ricciardelli-D'Albore, G. \& Intoppa, F. 2000. Apoidei e Ambiente. In: G. Ricciardelli d'Albore \& F. Intoppa (eds.). Fiori e Api. La flora visitata dalle Api e dagli altri Apoidei in Europa. Calderini Edagricole, Bologna, pp. 12-15.

Schuch, D.M.T., Tochetto, L.G. \& Sattler, A. 2003. Isolamento de esporos de Paenibacillus larvae subsp. larvae no Brasil. Pesquisa Agropecuária Brasileira 38: 441-444.

Shepherd, G.J. 1996. Fitopac 1: manual do usuário. Campinas: Departamento de Botânica, Universidade Estadual de Campinas.

Shimanuki, H. \& Knox, D.A. 1994. Susceptibility of Bacillus larvae to Terramycin. American Bee Journal 134: 125-126.

Shimanuki, H. \& Knox, D.A. 2000. Diagnosis of Honey Bee Diseases. U.S. Department of Agriculture, Agriculture Handbook No. AH-690.

Simpson, J. 1955. The significance of the presence of pollen in the food of worker larvae of honeybees. Quarterly Journal of Microscopical Science Archives 96: 117-120.

Song, X.Y., Yao, Y.F. \& Yang, W.D. 2012. Pollen Analysis of Natural Honeys from the Central Region of Shanxi, North China. PLoS One 7: e49545.

Stocker, A. 2005. Isolation and characterisation of substances from Royal Jelly. Thèse. Université d'Orléans, Université Technique de Munich. Available in https://tel.archives-ouvertes.fr/tel-00008586. (access in 14-III-2018).

Teixeira, E.W., Guimarães-Cestaro, L., Marques, M.L.T., Alves, F., Message, D., Martins, M.F., Luz, C.F.P. \& Serrão, J.E. 2018. Spores of Paenibacillus larvae, Ascosphaera apis, Nosema ceranae and Nosema apis in bee products supervised by the Brazilian Federal Inspection Service. Revista Brasileira de Entomologia (in press). 